\title{
The carbonate system in coastal waters off the northern region of the Baja California Peninsula under La Niña conditions
}

\section{El sistema de carbonatos en aguas costeras del norte de la península de Baja California bajo condiciones de La Niña}

\author{
Norma Oliva-Méndez ${ }^{1,2}$, Francisco Delgadillo-Hinojosa ${ }^{2}$, Paula Pérez-Brunius ${ }^{3}$, Augusto Valencia- \\ Gasti², Miguel A Huerta-Diaz², Eduardo Palacios-Coria ${ }^{4}$, J Martín Hernández-Ayón²* \\ ${ }^{1}$ Facultad de Ciencias Marinas, Universidad Autónoma de Baja California, Apartado Postal 453, Ensenada, \\ Baja California, Mexico. \\ 2 Instituto de Investigaciones Oceanológicas, Universidad Autónoma de Baja California, Apartado Postal 453 , \\ Ensenada, Baja California, Mexico. \\ 3 Departamento de Oceanografía Biológica, Centro de Investigación Científica y de Educación Superior de \\ Ensenada, Carretera Ensenada-Tijuana, no. 3918, Zona Playitas, CP 22860, Ensenada, Baja California, \\ Mexico. \\ ${ }^{4}$ Estación de Investigación Oceanográfica, Segunda Región Naval, Boulevard Costero y Agustín Sanguines \\ s/n, CP 22800, Ensenada, Baja California, Mexico. \\ * Corresponding author. E-mail: jmartin@uabc.edu.mx, ORCID ID: 0000-0001-6869-6225.
}

\begin{abstract}
In the North Pacific, variations in isopycnal depth influence the biogeochemical characteristics of the water column and the aragonite saturation horizon ( $\mathrm{Z} \Omega \mathrm{a}$ ) during interannual events. The objective of this study was to assess the effect of the $2011 \mathrm{La}$ Niña conditions on $\mathrm{Z} \Omega \mathrm{a}$ in Todos Santos Bay (Baja California, Mexico) and surrounding waters. The results showed that $\mathrm{Z} \Omega \mathrm{a}$ variability was modulated by the intensity of interannual conditions and by the water masses that were present in the region. Subarctic Water predominated in the upper $200 \mathrm{~m}$ with anomalous characteristics, such as low temperature and low salinity. Also, isopycnals shoaled toward the coast and Z $\Omega$ a was thus $\sim 30 \mathrm{~m}$ in the nearshore area, in contrast with the oceanic region, where $Z \Omega a$ was $\sim 150 \mathrm{~m}$. Prior to this study, there were no records of $Z \Omega \mathrm{a}$ in Todos Santos Bay, nor were there any records of its shallowness.
\end{abstract}

Key words: upwelling, aragonite saturation horizon, Todos Santos Bay, ocean acidification.

RESUMEN. En el Pacífico Norte se presentan variaciones en la profundidad de las isopicnas durante eventos interanuales que influyen en las características biogeoquímicas de la columna de agua y en el horizonte de saturación del aragonita (ZSa). El objetivo de este trabajo fue evaluar el efecto de las condiciones de La Niña de 2011 sobre el Z $\Omega$ a en la bahía de Todos Santos (Baja California, México) y aguas adyacentes. Los resultados mostraron que la variabilidad del $\mathrm{Z} \Omega \mathrm{a}$ estuvo modulada por la intensidad de las condiciones interanuales y por las masas de agua que se presentaron en la región. En los primeros 200 m superficiales predominó el Agua del Subártico con características anómalas de baja temperatura y baja salinidad. Asimismo, se observó un ascenso de las isopicnas con dirección a la costa y, por tanto, el Z $\mathrm{Za}$ fue de $\sim 30 \mathrm{~m}$ en la zona más cercana a la costa, en contraste con la región más oceánica, donde el Z $\Omega$ a fue de $\sim 150 \mathrm{~m}$. Antes del presente estudio, no se tenían registros del Z $\Omega$ a para la zona dentro de la bahía de Todos Santos, tampoco de que pudiera ser somero.

Palabras clave: surgencia, horizonte de saturación del aragonita, bahía de Todos Santos, acidificación del océano.

\section{INTRODUCTION}

Since the industrial revolution, absorption of anthropogenic carbon dioxide $\left(\mathrm{CO}_{2}\right)$ has reduced surface ocean $\mathrm{pH}$ by approximately 0.1 units (Feely et al. 2008). This decline is compensated for by the dissolution of carbonate minerals in the ocean (Archer et al. 1998, Ilyina and Zeebe 2012). For example, marine calcifying organisms precipitate calcium carbonate $\left(\mathrm{CaCO}_{3}\right)$ as calcite or aragonite. The presence of these 2 carbonate mineral species, commonly of biogenic origin, is defined by their potential solubility, that is, if water conditions favor their precipitation or dissolution, which is estimated by the saturation state $(\Omega)$. This

\section{INTRODUCCIÓN}

Desde la revolución industrial, la absorción del dióxido de carbono $\left(\mathrm{CO}_{2}\right)$ de origen antropogénico ha disminuido el $\mathrm{pH}$ en aproximadamente 0.1 unidades en la superficie del océano (Feely et al. 2008). Esta disminución se compensa con la disolución de minerales carbonatados en el océano (Archer et al. 1998, Ilyina y Zeebe 2012). Por ejemplo, los organismos calcificadores marinos precipitan el carbonato de calcio $\left(\mathrm{CaCO}_{3}\right)$ en forma de calcita o aragonita. La presencia de estas 2 especies minerales carbonatadas, comúnmente de origen biogénico, está definida por su solubilidad potencial, es decir, si las condiciones del agua favorecen su precipitación o disolución, 
parameter is defined as the product of calcium $\left(\mathrm{Ca}^{2+}\right)$ and carbonate ion $\left(\mathrm{CO}_{3}^{-2}\right)$ concentrations divided by the solubility product (Ksp) for the mineral phase:

$$
\begin{aligned}
& \Omega_{\text {aragonite }}(\Omega \mathrm{a})=\frac{\left[\mathrm{Ca}^{2+}\right]\left[\mathrm{CO}_{3}^{-2}\right]}{\mathrm{KpS}_{\text {aragonite }}}, \\
& \Omega_{\text {calcite }}(\Omega \mathrm{ca})=\frac{\left[\mathrm{Ca}^{2+}\right]\left[\mathrm{CO}_{3}^{-2}\right]}{\mathrm{KpS}_{\text {calcite }}},
\end{aligned}
$$

In regions where aragonite $\Omega(\Omega \mathrm{a})$ or calcite $\Omega(\Omega \mathrm{ca})$ is $>1$ the formation of carbonated structures (shells and exoskeletons) is favored, but when $\Omega$ a or $\Omega$ ca is $<1$, the dissolution of these structures may occur. The boundary between these 2 conditions ( $\Omega \mathrm{a}$ or $\Omega \mathrm{ca}=1$ ) is known as the saturation horizon (Feely et al. 2008). In surface waters, aragonite is approximately $50 \%$ more soluble than calcite (Doney et al. 2009). In fact, in the North Pacific the aragonite saturation horizon $(\mathrm{Z} \Omega \mathrm{a})$ is shallower $(50-100 \mathrm{~m})$ than the calcite saturation horizon $(\sim 500 \mathrm{~m})$ (Feely et al. 2004). However, $\mathrm{Z} \Omega \mathrm{a}$ has shoaled as anthropogenic $\mathrm{CO}_{2}$ has increased in the ocean. In this scenario, in coastal upwelling regions, water with $\Omega$ a values $<1$ can be transported to the surface more frequently and in larger volumes by this forcing and can thus create unfavorable conditions for the growth of calcifying organisms (Feely et al. 2008).

There are many factors modulating upwelling events in the California Current System (CCS): (1) interannual and decadal variations, (2) wind patterns, and (3) ocean surface circulation, which changes the distribution of water masses (Chhak and Di Lorenzo 2007). Variations in these factors can produce effects down to $250 \mathrm{~m}$ depth (Chhak and Di Lorenzo 2007). For example, Feely et al. (2008) found that, off the coast of Baja California (Mexico), $\mathrm{Z} \Omega \mathrm{a}$ oscillated between 50 and $70 \mathrm{~m}$, with a $\mathrm{pH}$ of $\sim 7.7$, during the 2007 upwelling season. Similarly, Linacre et al. (2010a) detected pulses of water with high dissolved inorganic carbon (DIC) contents $\left(\sim 2,200 \mu \mathrm{mol} \cdot \mathrm{kg}^{-1}\right)$ near the coast $(3 \mathrm{~km})$ and Todos Santos Bay (Baja California) during the 2008 La Niña event. Results from these studies suggest that the $\mathrm{CO}_{2}$ system variables in the water column can be modulated by interannual conditions such as La Niña. It is important to highlight that these are the only studies on the carbonate system that have been conducted near Todos Santos Bay.

Negative anomalies of up to $2{ }^{\circ} \mathrm{C}$ were observed from spring 2010 to early 2011 in the CCS region (Bjorkstedt et al. 2011). These thermal anomalies were attributed to La Niña conditions, which were characterized by the intrusion of a large volume of Subarctic Water (Bjorkstedt et al. 2011). In addition, the rise of the $26.0 \mathrm{~kg} \cdot \mathrm{m}^{-3}$ isopycnal was observed on line 90 of the California Cooperative Oceanic Fisheries Investigations (CalCOFI) program during the 2011 La Niña conditions (Jacox et al. 2016). This isopycnal is associated la cual se estima mediante el estado de saturación $(\Omega)$. Este parámetro se define como el producto de las concentraciones de calcio $\left(\mathrm{Ca}^{2+}\right)$ y del ion carbonato $\left(\mathrm{CO}_{3}^{-2}\right)$ dividido por el producto de solubilidad (Kps) de la fase mineral:

$$
\begin{aligned}
& \Omega_{\text {aragonita }}(\Omega \mathrm{a})=\frac{\left[\mathrm{Ca}^{2+}\right]\left[\mathrm{CO}_{3}^{-2}\right]}{\mathrm{KpS}_{\text {aragonita }}}, \\
& \Omega_{\text {calcita }}(\Omega \mathrm{ca})=\frac{\left[\mathrm{Ca}^{2+}\right]\left[\mathrm{CO}_{3}^{-2}\right]}{\mathrm{KpS}_{\text {callita }}},
\end{aligned}
$$

En regiones donde el $\Omega$ del aragonita $(\Omega$ a) o de la calcita $(\Omega \mathrm{ca})$ es $>1$ se favorece la formación de estructuras carbonatadas (conchas y exoesqueletos), pero si $\Omega$ a o $\Omega$ ca son $<1$ puede ocurrir la disolución de estas estructuras. El límite entre ambas condiciones $(\Omega \mathrm{a}$ o $\Omega \mathrm{ca}=1)$ se conoce como horizonte de saturación (Feely et al. 2008). En aguas superficiales, el aragonita es aproximadamente $50 \%$ más soluble que la calcita (Doney et al. 2009). De hecho, en el norte del océano Pacífico el horizonte de saturación del aragonita ( $\mathrm{Z} \Omega \mathrm{a})$ es más somero $(50-100 \mathrm{~m})$ en comparación con el de la calcita $(\sim 500 \mathrm{~m})$ (Feely et al. 2004). Sin embargo, el incremento de $\mathrm{CO}_{2}$ antropogénico en el océano ha provocado un ascenso del Z $\Omega$ a. Bajo este escenario, en regiones de surgencia costera, el agua con valores de $\Omega \mathrm{a}<1$ puede transportarse con mayor frecuencia y volumen hacia la superficie debido a este forzamiento y, por lo tanto, generar condiciones no adecuadas para el desarrollo de los organismos calcificadores (Feely et al. 2008).

Los eventos de surgencia en el Sistema de la Corriente de California (SCC) son modulados por diversos factores: (1) variaciones interanuales y decadales, (2) patrones de viento y (3) circulación superficial del océano, la cual cambia la distribución de las masas de agua (Chhak y Di Lorenzo 2007). La variación de estos factores puede generar efectos en los primeros $250 \mathrm{~m}$ de profundidad (Chhak y Di Lorenzo 2007). Por ejemplo, Feely et al. (2008) encontraron que, frente a las costas de Baja California (México), el Z 2 a osciló entre 50 y $70 \mathrm{~m}$ con un $\mathrm{pH}$ de $\sim 7.7$ durante la temporada de surgencias de 2007. De igual forma, Linacre et al. (2010a) detectaron pulsos de agua con alto contenido de carbono inorgánico disuelto (DIC, $\left.\sim 2,200 \mu \mathrm{mol} \cdot \mathrm{kg}^{-1}\right)$ cerca de la costa $(3 \mathrm{~km}$ ) y de la bahía de Todos Santos (Baja California) durante La Niña de 2008. Los resultados de estos trabajos sugieren que las variables del sistema del $\mathrm{CO}_{2}$ en la columna de agua pueden ser moduladas por condiciones interanuales, como La Niña. Es importante destacar que estos son los únicos estudios sobre el sistema de los carbonatos más cercanos a la bahía de Todos Santos.

Por otro lado, en la región del SCC se observaron anomalías negativas de hasta $2{ }^{\circ} \mathrm{C}$ desde la primavera de 2010 hasta el inicio de 2011 (Bjorkstedt et al. 2011). Estas anomalías térmicas se atribuyeron a las condiciones de La Niña, la cual se caracterizó por la intrusión de un mayor volumen de agua de origen subártico (Bjorkstedt et al. 2011). Además, en la línea 90 del programa California Cooperative Oceanic Fisheries 
with the of the nutricline, and costal upwelling events further promote its upward movement toward the coast (Lynn et al. 2003).

These type of changes in oceanographic conditions could modulate variations in the $\mathrm{CO}_{2}$ system in the CCS. For example, the sinking of the $26.0 \mathrm{~kg} \cdot \mathrm{m}^{-3}$ isopycnal during the 2010 El Niño conditions and its upward movement as La Niña conditions developed were detected on line 90 of the CalCOFI program; however, the effects of these phenomena on the $\mathrm{CO}_{2}$ system variables were not reported (Jacox et al. 2016). A series of empirical equations that allow for the reconstruction of the seasonality and long-term trend of the possible effects of ocean acidification were recently developed. These equations were generated for coastal waters in the CCS (including the northern region off the coast of Baja California) in a way that hydrographic data could be used as an alternative when measurements of the carbonate system are insufficient (Juranek et al. 2009, Alin et al. 2012). Taking all the above into account, the aim of this study was to assess the effects of the 2011 La Niña event on Z $\Omega$ a in Todos Santos Bay and adjacent waters.

\section{Materials ANd Methods}

\section{Study area}

Todos Santos Bay (TSB) $\left(31.85^{\circ} \mathrm{N}, 116.75^{\circ} \mathrm{W}\right)$ has an area of $\sim 180 \mathrm{~km}^{2}$ and an average depth of $40 \mathrm{~m}$ (Fig. 1). This bay connects with the Pacific Ocean through an entrance to the north $(\sim 10 \mathrm{~km}$ wide and $\sim 30 \mathrm{~m}$ deep) and an entrance to the south ( $\sim 4 \mathrm{~km}$ wide and $\sim 450 \mathrm{~m}$ deep, Flores-Vidal et al. 2015).

During periods of intense wind blowing parallel to the coast, wind promotes the flow of water from outside TSB to the innermost part of the bay (Flores-Vidal et al. 2015). When winds weaken, this water (of upwelling origin) can remain trapped in TSB. The characteristics of the CCS are thus restricted to the area adjacent to TSB and, as a result, the physical and biochemical properties of water can be different in and out of the bay. For example, in 2008, there were differences in average sea surface temperature in $\left(17.74 \pm 0.42^{\circ} \mathrm{C}\right)$ and out $\left(14.67 \pm 0.52^{\circ} \mathrm{C}\right)$ of TSB (Delgadillo-Hinojosa et al. 2015). The difference in temperatures was due to the heat the CCS water gained as it entered TSB. The possible influence of upwelled waters toward the inner part of TSB has also been reported (Zaytsev et al. 2003, Perez-Brunius et al. 2007).

\section{Sampling design}

During 2011, 4 cruises were carried out aboard the $\mathrm{R} / \mathrm{V}$ Francisco de Ulloa to characterize the spatial and temporal distribution of the $\mathrm{CO}_{2}$ system variables in TSB.
Investigations (CalCOFI) se observó el ascenso de la isopicna de $26.0 \mathrm{~kg} \cdot \mathrm{m}^{-3}$ durante las condiciones de La Niña de 2011 (Jacox et al. 2016). Esta isopicna se asocia con la profundidad de la nutriclina, y los eventos de surgencias costeras provocan aún más su ascenso hacia la costa (Lynn et al. 2003).

Este tipo de cambios en las condiciones oceanográficas podrían modular las variaciones del sistema del $\mathrm{CO}_{2}$ en el SCC. Por ejemplo, en la línea 90 del programa CalCOFI se detectó el hundimiento de la isopicna de $26.0 \mathrm{~kg} \cdot \mathrm{m}^{-3}$ durante las condiciones de El Niño de 2010 y su ascenso conforme al desarrollo de las condiciones de La Niña; sin embargo, no se reportaron los efectos de estos fenómenos sobre las variables del sistema del $\mathrm{CO}_{2}$ (Jacox et al. 2016). Recientemente, se han generado una serie de ecuaciones empíricas que permiten reconstruir la estacionalidad y tendencia a largo plazo de los posibles efectos de la acidificación del océano. Dichas ecuaciones se generaron para las aguas costeras del SCC (incluye la región norte frente a las costas de Baja California) de manera que sea posible utilizar datos hidrográficos como una opción cuando no se tienen suficientes mediciones del sistema de los carbonatos (Juranek et al. 2009, Alin et al. 2012). A partir de lo anterior, el objetivo de este trabajo fue evaluar el efecto de La Niña de 2011 sobre el Z $\Omega$ a en la bahía de Todos Santos y aguas adyacentes.

\section{MATERIALES Y MÉTODOS}

\section{Área de estudio}

La bahía de Todos Santos (BTS) $\left(31.85^{\circ} \mathrm{N}, 116.75^{\circ} \mathrm{W}\right)$ tiene un área de $\sim 180 \mathrm{~km}^{2}$ y una profundidad promedio de $40 \mathrm{~m}$ (Fig. 1). Esta bahía se comunica con el océano Pacífico mediante una entrada norte $(\sim 10 \mathrm{~km}$ de ancho y $\sim 30 \mathrm{~m}$ de profundidad) y una entrada sur ( $\sim 4 \mathrm{~km}$ de ancho y $\sim 450 \mathrm{~m}$ de profundidad, Flores-Vidal et al. 2015).

Durante los periodos de vientos intensos paralelos a la costa, los vientos promueven un flujo de agua desde fuera de la BTS hacia la parte más interna de la BTS (Flores-Vidal et al. 2015). Cuando los vientos disminuyen, esta agua (que tiene su origen en surgencias) puede quedar atrapada dentro de la BTS. De esta manera, las características del SCC se restringen a la zona aledaña a la BTS, por lo que las propiedades físicas y biogeoquímicas del agua pueden ser diferentes dentro y fuera de la bahía. Por ejemplo, en el año 2008 se detectaron diferencias en el promedio de la temperatura superficial del mar dentro $\left(17.74 \pm 0.42{ }^{\circ} \mathrm{C}\right)$ y fuera $\left(14.67 \pm 0.52{ }^{\circ} \mathrm{C}\right)$ de la BTS (Delgadillo-Hinojosa et al. 2015). La diferencia en las temperaturas se debió a que el agua del SCC que entró a la BTS adquirió calor. Se ha reportado, también, la posible influencia de aguas de surgencia hacia el interior de la BTS (Zaytsev et al. 2003, Perez-Brunius et al. 2007).

\section{Diseño del muestreo}

Durante 2011, se realizaron 4 cruceros a bordo del B/O Francisco de Ulloa para caracterizar la distribución espacial 


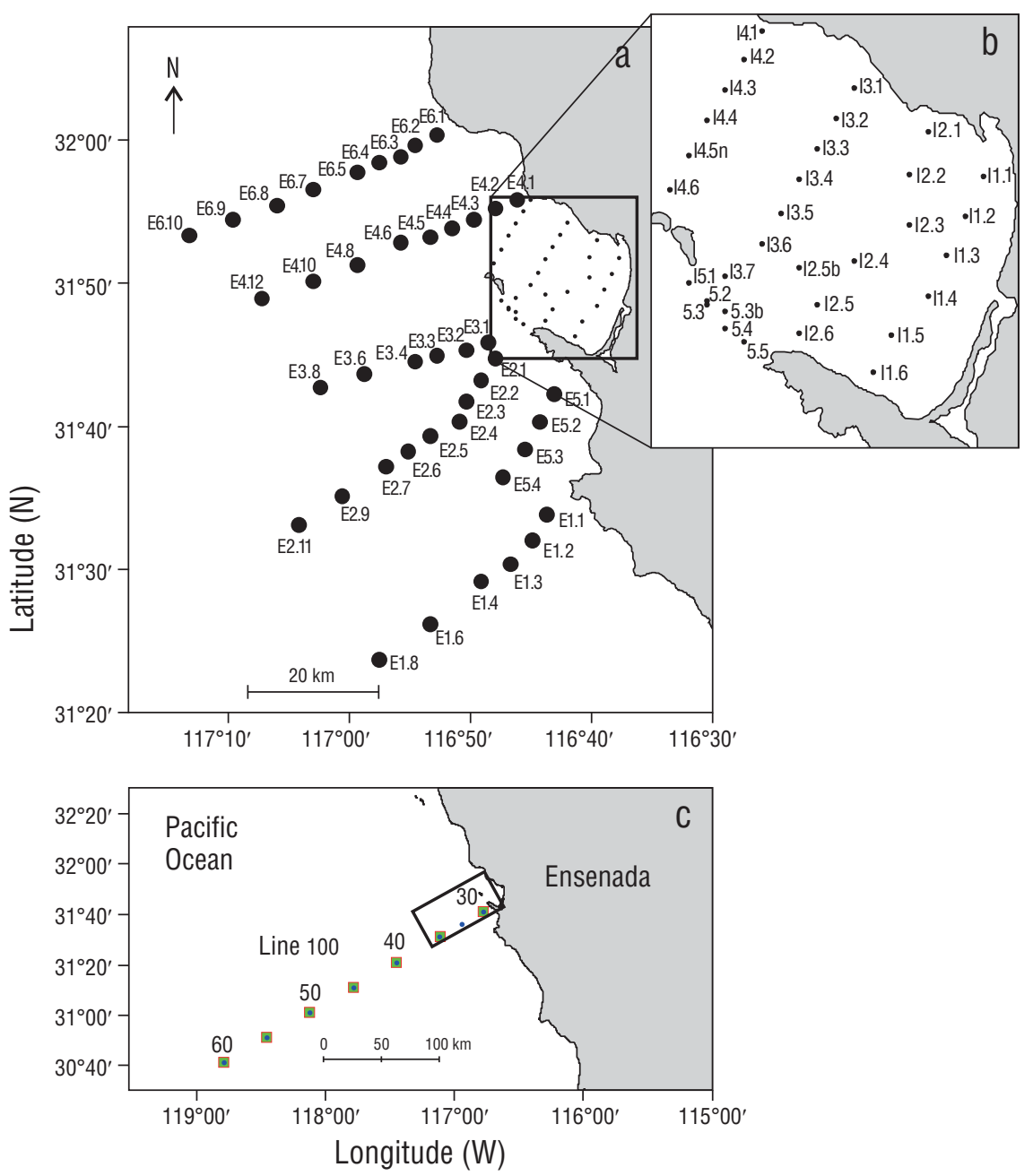

Figure 1. Map showing the IMECOCAL transects and the sampling stations in Todos Santos Bay where the CTD measurements were recorded in 2011: (a) outer stations, (b) inner stations. (c) Hydrographic stations along line 100 of the IMECOCAL program. The rectangle in (c) indicates the stations $(100.30,100.32$, and 100.35) that were used as climatological references.

Figura 1. Mapa que muestra los transectos del programa IMECOCAL y las estaciones de muestreo en la bahía de Todos Santos donde se registraron las mediciones de CTD en 2011: (a) estaciones externas y (b) estaciones internas. (c) Estaciones hidrográficas a lo largo de la línea 100 del programa IMECOCAL. El rectángulo en (c) indica las estaciones (100.30, 100.32 y 100.35) que se usaron como referencias climatológicas.

The cruises were classified based on the seasonal period in which they were carried out: February (winter), May (spring), August (summer), and November (autumn). During these cruises temperature $\left({ }^{\circ} \mathrm{C}\right)$, salinity, and dissolved oxygen $\left(\mu \mathrm{mol} \cdot \mathrm{kg}^{-1}\right)$ were measured by making conductivity, temperature, and depth (CTD SBE 9/11) casts in TSB and the adjacent coastal zone (Fig. 1). Seventy-four hydrographic stations were sampled during each cruise, 32 of which were located in TSB (inner stations) and the rest were distributed into 4 transects perpendicular to the coastline and 1 transect at the southern entrance. During each campaign, water samples were collected with 5-L Niskin bottles at standard depths $(0,10$, $20,50,100,150$, and $200 \mathrm{~m}$ ) to determine DIC and total alkalinity. y temporal de las variables del sistema del $\mathrm{CO}_{2}$ en la BTS. Los cruceros se clasificaron con base en el periodo estacional en el que se llevaron a cabo: febrero (invierno), mayo (primavera), agosto (verano) y noviembre (otoño). Durante estos cruceros se realizaron mediciones de temperatura $\left({ }^{\circ} \mathrm{C}\right)$, salinidad y oxígeno disuelto $\left(\mu \mathrm{mol} \cdot \mathrm{kg}^{-1}\right)$ mediante lances de conductividad, temperatura y profundidad (CTD SBE 9/11) en la BTS y su zona costera aledaña (Fig. 1). Se muestrearon 74 estaciones hidrográficas en cada crucero, de las cuales 32 correspondieron a estaciones internas ubicadas dentro de la BTS y el resto se distribuyeron en 4 transectos transversales y 1 transecto en la entrada sur. En cada campaña se recolectaron muestras de agua con botellas Niskin de $5 \mathrm{~L}$ de capacidad a profundidades estándar $(0,10,20,50,100,150$ y $200 \mathrm{~m}$ ) para la determinación del DIC y la alcalinidad total. 


\section{Water masses}

Water masses in the study area were identified with a hydrographic analysis using temperature and salinity diagrams ( $\mathrm{T}-\mathrm{S}$ diagrams) and the classification by Durazo and Baumgartner (2002).

\section{Dissolved inorganic carbon and total alkalinity analyses}

DIC in the water samples was analyzed using the coulometric system described by Johnson et al. (1987), while total alkalinity was measured by potentiometry according to Hernández-Ayón et al. (1999). Calibrations for both analyses were done with certified reference material (Marine Physical Laboratory at Scripps Institution of Oceanography, headed by Dr. Andrew Dickson), with which a $\pm 3 \mu$ mol precision and a $1.5 \%$ error were obtained. $\Omega$ a was calculated using the CO2Sys program (Lewis and Wallace 1998) and by taking the DIC-total alkalinity pair, temperature, salinity, pressure, and the dissociation constants by Mehrbach et al. (1973) into account.

\section{Empirical model for the reconstruction of $\mathrm{pH}, \Omega \mathrm{a}$, and dissolved inorganic carbon}

With the CTD hydrographic data $\mathrm{pH}, \Omega \mathrm{a}$, and DIC were calculated for each of the 4 cruises using the empirical relationships proposed by Alin et al. (2012):

\section{Masas de agua}

Las masas de agua presentes en el área de estudio se identificaron por medio de un análisis hidrográfico usando diagramas de temperatura y salinidad (diagramas T-S) y la clasificación de Durazo y Baumgartner (2002).

\section{Análisis de carbono inorgánico disuelto y alcalinidad total}

El análisis de DIC de las muestras de agua se realizó con el sistema coulométrico descrito por Johnson et al. (1987), mientras que la alcalinidad total se midió por potenciometría de acuerdo con Hernández-Ayón et al. (1999). Para ambos análisis se efectuaron calibraciones con material de referencia certificado (Marine Physical Laboratory del Scripps Institution of Oceanography, a cargo del Dr. Andrew Dickson), con el cual se obtuvo una precisión de $\pm 3 \mu \mathrm{mol}$ y un error de $1.5 \%$. El $\Omega$ a se calculó utilizando el programa CO2Sys (Lewis y Wallace 1998) y considerando la pareja DIC-alcalinidad total, la temperatura, la salinidad, la presión y las constantes de disociación de Mehrbach et al. (1973).

\section{Modelo empírico de reconstrucción del $\mathrm{pH}, \Omega \mathrm{a}$ y carbono inorgánico disuelto}

A partir de los datos hidrográficos del CTD, se calculó el $\mathrm{pH}, \Omega \mathrm{a}$ y DIC para cada uno de los 4 cruceros utilizando las relaciones empíricas propuestas por Alin et al. (2012):

$$
\begin{gathered}
\Omega_{a}^{e s t}=\alpha_{0}+\alpha_{1}\left(T-T_{r}\right)+\alpha_{2}\left(O_{2}-O_{2 r}\right)+\alpha_{3}\left[\left(T-T_{r}\right) \times\left(O_{2}-O_{2 r}\right)\right], \\
p H^{e s t}=\alpha_{0}+\alpha_{1}\left(T-T_{r}\right)+\alpha_{2}\left(O_{2}-O_{2 r}\right)+\alpha_{3}\left[\left(T-T_{r}\right) \times\left(O_{2}-O_{2 r}\right)\right], \\
D I C^{e s t}=\alpha_{0}+\alpha_{1}\left(\sigma_{\theta}-\sigma_{r}\right)+\alpha_{2}\left(O_{2}-O_{2 r}\right)+\alpha_{3}\left[\left(\sigma_{\theta}-\sigma_{\theta r}\right) \times\left(O_{2}-O_{2 r}\right)\right],
\end{gathered}
$$

where $T$ is temperature $\left({ }^{\circ} \mathrm{C}\right), S$ is salinity, $\mathrm{O}_{2}$ is dissolved oxygen $\left(\mu \mathrm{mol} \cdot \mathrm{kg}^{-1}\right), \sigma_{\theta}$ is the potential density anomaly $\left(\mathrm{kg} \cdot \mathrm{m}^{-3}\right)$, and $\alpha$ is the coefficient estimated for each model; subscript $r$ indicates reference values and superscript est indicates estimated values (Alin et al. 2012). The estimations provide information on the average state of the $\mathrm{CO}_{2}$ system variables in waters between 15 and $500 \mathrm{~m}$ depth for any moment between 1997 and 2017. The equations can be used for sites with limited observations on the carbon variables, and these variables in turn can subsequently be used to calibrate the model. Validation of this methodology was done by comparing the DIC and $\Omega \mathrm{a}$ values from the samples collected during the oceanographic campaigns with the values produced by the model (Fig. 2). On Figure 2 we also superimposed the data obtained for line 100 during the National Oceanic and Atmospheric Administration (NOAA, USA) (WC200705) cruise in May-June 2007. donde $T$ es la temperatura $\left({ }^{\circ} \mathrm{C}\right), S$ es la salinidad, $O_{2}$ es el oxígeno disuelto $\left(\mu \mathrm{mol} \cdot \mathrm{kg}^{-1}\right), \sigma_{\theta}$ es la anomalía de densidad potencial $\left(\mathrm{kg} \cdot \mathrm{m}^{-3}\right)$, y $\alpha$ es el coeficiente calculado para cada modelo; el subíndice $r$ indica valores de referencia y el superíndice est indica valores estimados (Alin et al. 2012). Las estimaciones permiten conocer el estado promedio de las variables del sistema del $\mathrm{CO}_{2}$ en aguas entre 15 y $500 \mathrm{~m}$ de profundidad en cualquier momento comprendido entre 1997 y 2017. Las ecuaciones pueden aplicarse para sitios con un limitado número de observaciones de las variables del carbono, mismas que posteriormente sirven para la calibración del modelo. La validación de esta metodología se realizó comparando los valores de DIC y $\Omega$ a de las muestras recolectadas en las campañas oceanográficas con los valores generados por el modelo (Fig. 2). Se sobrepusieron, también, en la Figura 2 los datos de la línea 100 generados durante el crucero de la Administración Nacional Oceánica y Atmosférica 


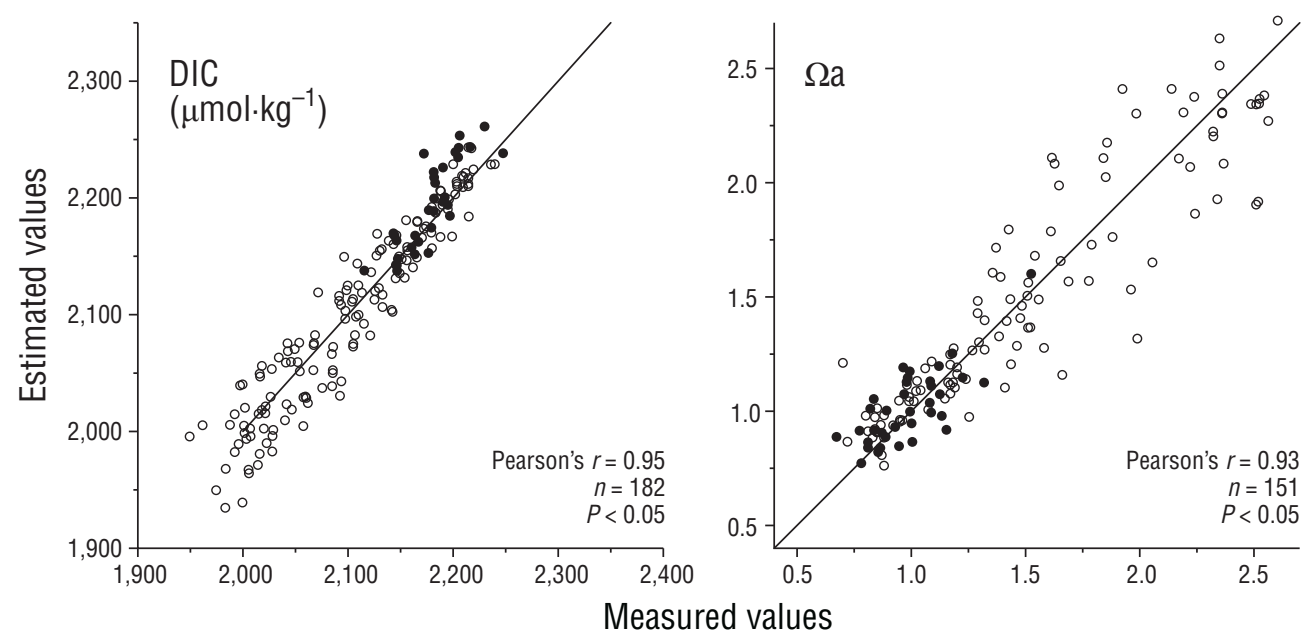

Figure 2. Measured versus estimated values for dissolved inorganic carbon (DIC) and aragonite saturation state ( $\Omega$ a). White circles correspond to samples collected off the coast of Baja California during a cruise carried out by the North American Carbon Program in May 2007 and black circles correspond to samples collected during the present study in 2011.

Figura 2. Valores medidos versus valores estimados para el carbono inorgánico disuelto (DIC) y el estado de saturación del aragonita $(\Omega \mathrm{a})$. Los círculos blancos corresponden a las muestras recolectadas frente a la costa de Baja California durante un crucero realizado por el North American Carbon Program en mayo de 2007 y los círculos negros corresponden a las muestras recolectadas en 2011 durante el presente estudio.

The statistical analysis shows that the DIC and $\Omega$ a values obtained with the empirical relationships were similar to the measured values obtained during the 4 cruises (DIC: $r_{\text {pearson }}=$ $0.95, n=182, P<0.05 ; \Omega$ a: rpearson $=0.93, n=151, P<0.05)$.

\section{Oceanographic climatology off Todos Santos Bay}

Line 100 of the IMECOCAL (Spanish acronym for Mexican Investigations of the California Current) program corresponds to the section nearest TSB, and hydrographic data for it covers from 1997 to 2016 (Fig. 1c). Therefore, in addition to average data, temperature and salinity measurements obtained in 2011 at the nearshore stations on this line (stations 100.30, 100.32, and 100.35) were used as reference for oceanographic conditions in our study region.

Our study in TSB was carried out under La Niña conditions. This was evidenced by Oceanic Niño Index (ONI) values ranging from -0.5 to -1.5 (Fig. 3), which indicate the presence of a negative sea surface temperature anomaly (http://www.cpc.ncep.noaa.gov/products/analysis_monitoring/ensostuff/ensoyears_1971-2000_climo.shtml). In the analysis we also included the monthly upwelling index for the past 7 years (https://www.pfeg.noaa.gov/products/PFELData/upwell/monthly/upanoms.mon), together with the ONI and upwelling index standardized anomalies for contrast with ONI (Fig. 3).

To assess if the physical changes that occurred in 2011 were influenced by La Niña conditions, the relationship between the depth of the Subarctic Water lower limit (ZSAW, defined by the $25.9 \mathrm{~kg} \cdot \mathrm{m}^{-3}$ isopycnal) and the
(NOAA, por sus siglas en inglés) de los Estados Unidos (WC200705) en mayo-junio de 2007.

El análisis estadístico muestra que los valores de DIC y $\Omega$ a obtenidos con las relaciones empíricas fueron muy similares a los valores medidos durante los 4 cruceros (DIC: $r_{\text {pearson }}=$ $0.95, n=182, P<0.05 ; \Omega$ a: $\left.r_{\text {pearson }}=0.93, n=151, P<0.05\right)$.

\section{Climatologías de las condiciones oceanográficas frente a la bahía de Todos Santos}

La línea 100 del programa Investigaciones Mexicanas de la Corriente de California (IMECOCAL) corresponde a la sección más cercana a la BTS y cuenta con datos hidrográficos que abarcan de 1997 a 2016 (Fig. 1c). Por ello, además de utilizar datos promedio, se utilizaron las mediciones de temperatura y salinidad realizadas durante 2011 en las estaciones más costeras de esta línea (estaciones 100.30, 100.32 y 100.35) como referencia de las condiciones oceanográficas que se presentan en nuestra región de estudio.

Nuestro estudio en la BTS se llevó a cabo bajo condiciones de La Niña. Como evidencia de ello, el Índice Oceánico de El Niño (ONI, por sus siglas en inglés) presentó valores de -0.5 a -1.5 (Fig. 3), lo cual indica la presencia de una anomalía negativa de la temperatura superficial del mar (http://www. cpc.ncep.noaa.gov/products/analysis_monitoring/ensostuff/ ensoyears_1971-2000_climo.shtml). Además, en el análisis se incluyó el índice de surgencia mensual de los últimos 7 años (https://www.pfeg.noaa.gov/products/PFELData/upwell/ monthly/upanoms.mon), así como las anomalías estandarizadas del ONI y del índice de surgencia para su contraste con el ONI (Fig. 3). 
ONI values for each cruise was estimated. This analysis was done for the winters (December and February) in the period from 1998 to 2012 at stations 100.30, 100.32, and 100.35 of the IMECOCAL program. The depth of the core of the California Countercurrent (ZCCc, defined by the $26.5 \mathrm{~kg} \cdot \mathrm{m}^{-3}$ isopycnal) was also located. Isopycnals were chosen by following the definition by Durazo (2015) and by detecting the temperature and salinity limits in the climatology of the water masses determined by the $\mathrm{T}-\mathrm{S}$ diagrams.

\section{ReSUlts}

\section{Hydrographic conditions (2011) and climatological conditions (1997-2016)}

The $\mathrm{T}-\mathrm{S}$ diagrams for transect $\mathrm{E} 1$ in the 4 cruises and for the IMECOCAL stations (100.30, 100.32, and 100.35) showed seasonal variation (Fig. 4) associated with the presence of less saline $(\sim 33.3)$ and colder $\left(15^{\circ} \mathrm{C}\right)$ water. Anomalously cool and less saline Subarctic Water (SAW) was observed from the surface to $200 \mathrm{~m}$ depth in winter (Fig. 4a), from the surface to $\sim 100 \mathrm{~m}$ depth in spring (Fig. 4b), and from $\sim 100 \mathrm{~m}$ down to $200 \mathrm{~m}$ depth in summer (Fig. 4c). In autumn, the depth of the $25.0 \mathrm{~kg} \cdot \mathrm{m}^{-3}$ isopycnal was similar to that of the climatological record. By contrast, the T-S diagram for transect E1, located to the south of TSB, showed
Para evaluar si los cambios físicos ocurridos en 2011 se debieron a la influencia de las condiciones de La Niña, se estimó la relación entre la profundidad del límite inferior del Agua del Subártico (ZASA, definida por la isopicna de $25.9 \mathrm{~kg} \cdot \mathrm{m}^{-3}$ ) y los valores del ONI correspondientes a cada crucero. Este análisis se realizó para los inviernos (diciembre y febrero) de 1998 a 2012 en las estaciones 100.30, 100.32 y 100.35 del programa IMECOCAL. También, se ubicó la profundidad que corresponde al núcleo de la contracorriente de California (ZCcC, definida por la isopicna de $26.5 \mathrm{~kg} \cdot \mathrm{m}^{-3}$ ). Las isopicnas se eligieron siguiendo la definición de Durazo (2015) y con base en los límites de temperatura y salinidad detectados en la climatología de las masas de agua determinadas a partir de los diagramas T-S.

\section{Resultados}

\section{Condiciones hidrográficas (2011) y condiciones climatológicas (1997-2016)}

Los diagramas T-S para el transecto E1 de los 4 cruceros y para las estaciones del programa IMECOCAL $(100.30,100.32$ y 100.35$)$ mostraron una variación estacional (Fig. 4) asociada con la presencia de aguas menos salinas $(\sim 33.3)$ y más frías $\left(15^{\circ} \mathrm{C}\right)$. Agua del Subártico (ASA) anómalamente fría y menos salina fue observada

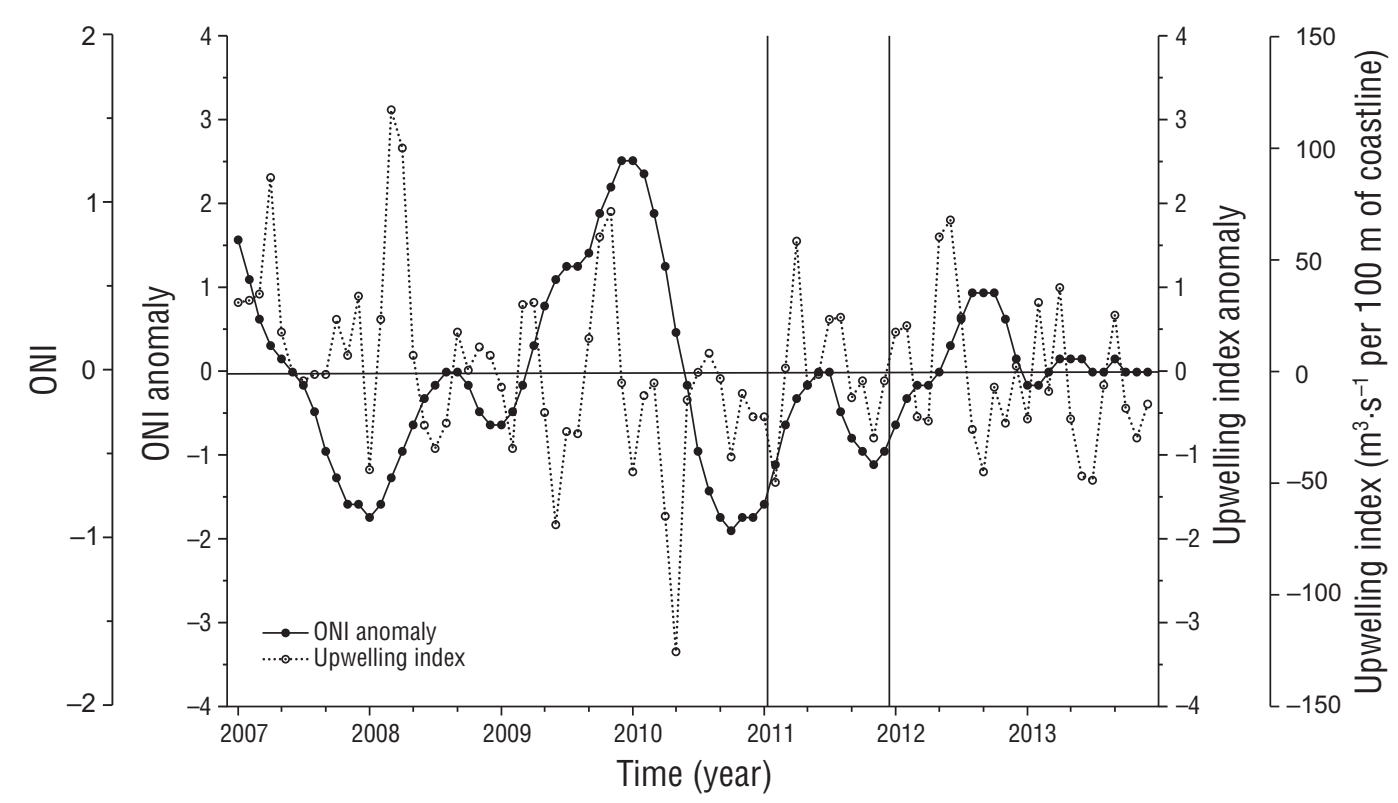

Figure 3. Monthly Oceanic Niño Index (ONI) anomalies (solid line) and upwelling index anomalies (dotted line) for the period from January 2007 to December 2013. Vertical lines indicate the sampling period for our study. Upwelling indices were obtained from https://www.pfeg. noaa.gov/products/PFELData/upwell/monthly/upanoms.mon and ONI were obtained from http://www.cpc.ncep.noaa.gov/products/analysis_monitoring/ensostuff/ensoyears_1971-2000_climo.shtml.

Figura 3. Anomalías mensuales del Índice Oceánico de El Niño (ONI, línea continua) y anomalías del índice de surgencia (línea punteada) para el periodo entre enero de 2007 y diciembre de 2013. Las líneas verticales indican el periodo de muestreo para nuestro estudio. Los índices de surgencia se obtuvieron de https://www.pfeg.noaa.gov/products/PFELData/upwell/monthly/upanoms.mon y los valores de ONI se obtuvieron de http://www.cpc.ncep.noaa.gov/products/analysis_monitoring/ensostuff/ensoyears_1971-2000_climo.shtml. 
IMECOCAL
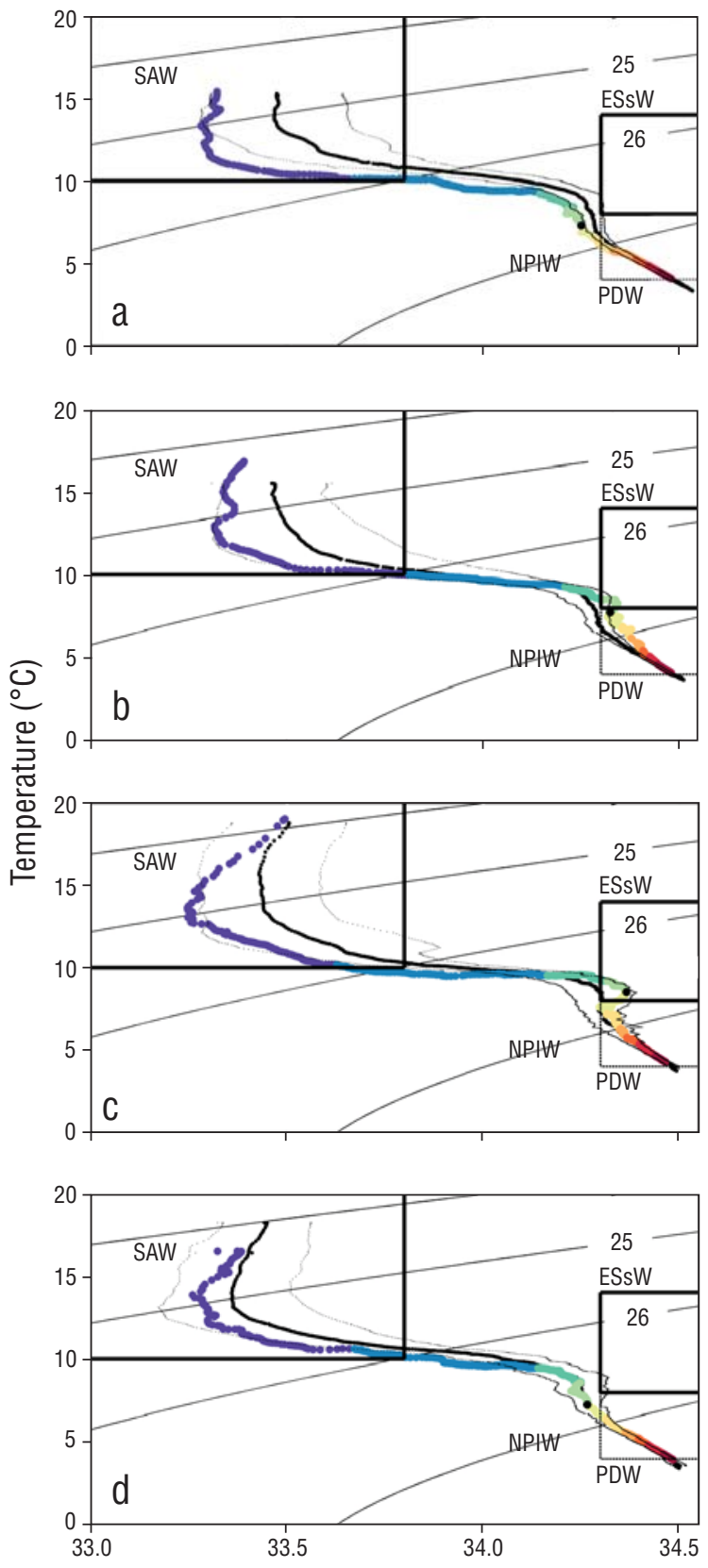

Todos Santos Bay
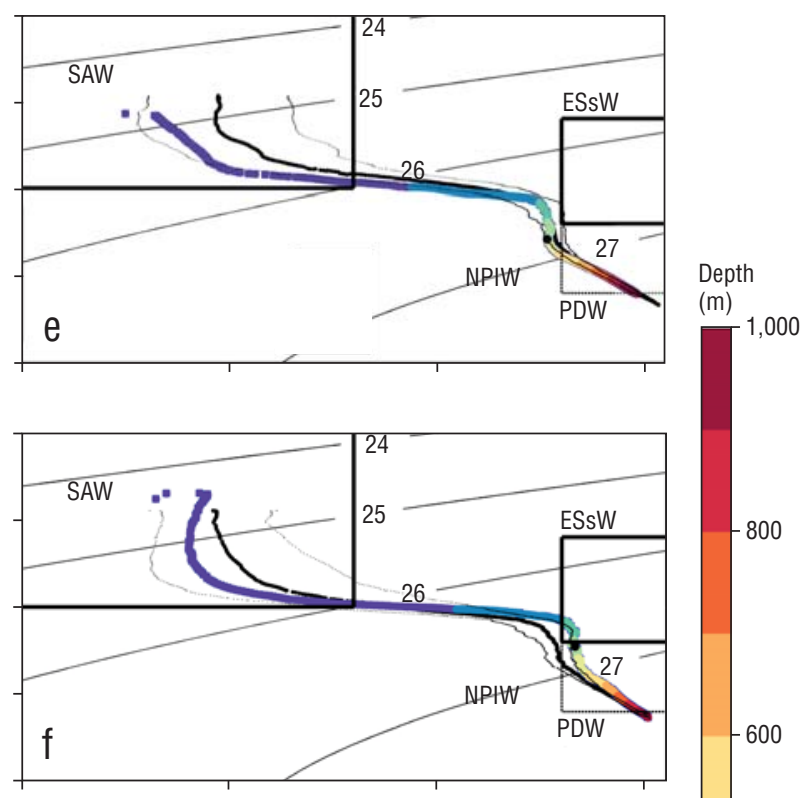

$-600$

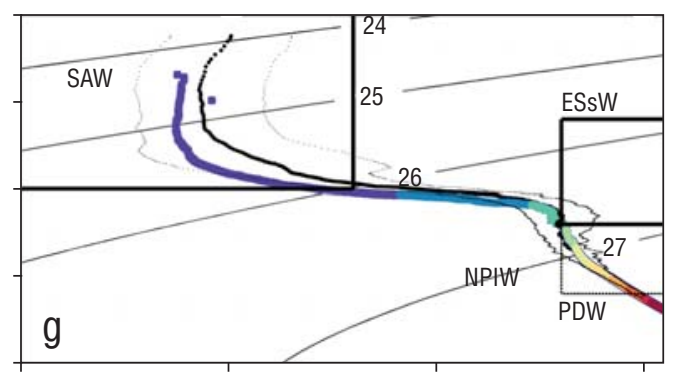

200

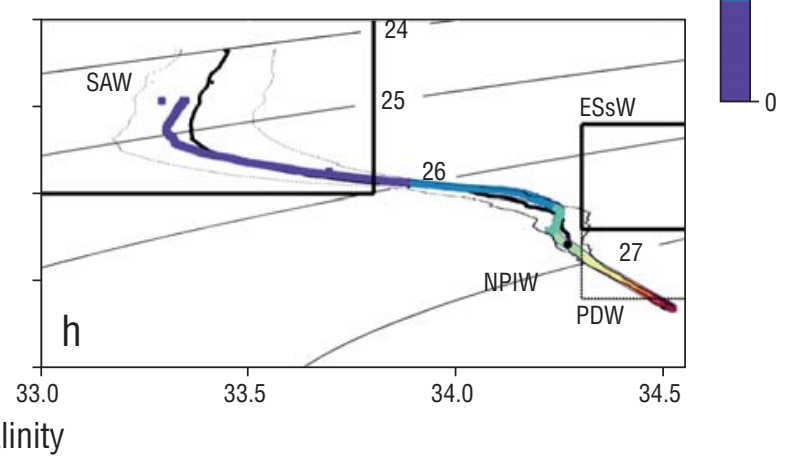

Figure 4. Temperature-salinity curves with reference to depth measured along line 100 of the IMECOCAL program during 2011 (a, b, c, d) and along transect E1 outside Todos Santos Bay in 2011 during winter, spring, summer, and autumn (e, f, g, h). The black continuous line represents the long-term mean obtained from data recorded by the IMECOCAL program between 1998 and 2017 and the thick black discontinuous lines represent the standard deviation. Water masses are Subarctic Water (SAW), Equatorial Subsurface Water (ESsW), North Pacific Intermediate Water (NPIW), and Pacific Deep Water (PDW).

Figura 4. Diagramas de temperatura y salinidad con respecto a la profundidad medida a lo largo de la línea 100 del programa IMECOCAL durante 2011 (a, b, c, d) y a lo largo del transecto E1 fuera de la bahía de Todos Santos en 2011 durante invierno, primavera, verano y otoño $(\mathbf{e}, \mathbf{f}, \mathbf{g}, \mathbf{h})$. La línea negra continua representa el promedio a largo plazo obtenido de los datos registrados por el programa IMECOCAL entre 1998 y 2017 y las líneas negras gruesas discontinuas representan la desviación estándar. Las masas de agua son Agua del Subártico (SAW), Agua Ecuatorial Subsuperficial (ESsW), Agua Intermedia del Pacífico Norte (NPIW) y Agua Profunda del Pacífico (PDW). 
Oliva-Méndez et al.: The carbonate system during La Niña off northern Baja California

hydrographic conditions that were close to the climatological average (Fig. 4b, d, f, g).

\section{Seasonality of water masses}

The SAW lower limit was located at different depths in every season (Fig. 5). For example, in winter, on transect E1, there was an upward movement of ZSAW from $100 \mathrm{~m}$ to $\sim 50 \mathrm{~m}$ toward the coast, whereas ZCCc sank from 200 to $250 \mathrm{~m}$ toward the coast. The upward movement of isopycnals was less pronounced in spring than in winter; ZSAW rose from 100 to $\sim 60 \mathrm{~m}$, but ZCCc remained somewhere between 170 and $200 \mathrm{~m}$ (Fig. 5). In summer, ZSAW persisted at $\sim 70 \pm 7 \mathrm{~m}$ and ZCCc was detected near the coast at $\sim 300 \mathrm{~m}$. In autumn, ZSAW $(\sim 125 \mathrm{~m})$ was deeper and ZCCc $(\sim 250 \mathrm{~m})$ was slightly shallower than in the previous season.

\section{Seasonality of the $\mathrm{CO}_{2}$ system variables}

The seasonal variation of the $\mathrm{CO}_{2}$ system variables was consistent with the distribution of the water masses. For example, water with high DIC content $\left(\sim 2,180 \mu \mathrm{mol} \cdot \mathrm{kg}^{-1}\right)$ and low $\Omega$ a values was detected in winter, when Isopycnals rose to $\sim 80 \mathrm{~m}$ depth toward the coast (Fig. 5). The shallowest $\mathrm{Z} \Omega \mathrm{a}$ value near the coast was not found during the season with the most intense coastal upwelling (spring-summer), but in winter. Furthermore, the greatest upward movement of isopycnals toward the coast coincided with the season during which La Niña was most intense.

\section{Influence of interannual conditions}

The relationship between ZSAW and ONI showed that when ONI values were negative ZSAW shoaled (Fig. 6). For example, during the 2010-2011 winter and under La Niña conditions, ZSAW was located at $102 \mathrm{~m}$ and ONI values were $-1.3^{\circ} \mathrm{C}$. Conversely, in the winter of 1998, under El Niño conditions, ZSAW was located at $162 \mathrm{~m}$ and ONI was $+2.1^{\circ} \mathrm{C}$. According to the linear regression analysis, ONI explained $60 \%\left(r^{2}=0.6, P<0.01, n=12\right)$ of the seasonal variability in the position of ZSAW.

The inner sampling stations and those adjacent to TSB had saline waters (>33.4) and $\Omega$ a values less than 1.6. However, the opposite scenario was observed outside TSB because of the dominance of SAW (mainly in winter) (Fig. 7). During winter, a north-south front parallel to the coast separated TSB water from adjacent waters, which were low in salinity $(<33.3)$ and high in $\Omega$ a values $(>2.2)$. Furthermore, characteristics similar to the winter conditions were found in spring. In summer, less-saline water ( $\sim 33.3$ ) with $\Omega$ a values of $\sim 2.2$ was distributed mainly to the northwest of the sampling zone. The opposite of what was observed during summer occurred during autumn, with less-saline water in the study area occurring from north to south as an intrusion (Fig. 7d). desde la superficie hasta $200 \mathrm{~m}$ de profundidad en invierno (Fig. 4a), desde la superficie hasta $\sim 100 \mathrm{~m}$ de profundidad en primavera (Fig. 4b) y desde $\sim 100 \mathrm{~m}$ hasta $200 \mathrm{~m}$ de profundidad en verano (Fig. 4c). Durante el otoño, la profundidad de la isopicna de $25.0 \mathrm{~kg} \cdot \mathrm{m}^{-3}$ fue similar a la del registro climatológico. En contraste, el diagrama T-S del transecto E1, localizado al sur de la BTS, mostró condiciones hidrográficas cercanas al promedio climatológico (Fig. 4b, d, f, g).

\section{Estacionalidad de las masas de agua}

El límite inferior del ASA se localizó a diferentes profundidades en cada estación del año (Fig. 5). Por ejemplo, en el invierno, en el transecto E1 se observó un claro ascenso de la ZASA de 100 a $\sim 50 \mathrm{~m}$ hacia la costa, mientras que la ZCcC se hundió de 200 a $250 \mathrm{~m}$ en dirección hacia la costa. El ascenso de las isopicnas en la primavera fue menos pronunciado que en el invierno; la ZASA ascendió de 100 a $\sim 60 \mathrm{~m}$, mientras que la ZCcC se mantuvo entre 170 y $200 \mathrm{~m}$ (Fig. 5). En el verano, la ZASA se mantuvo a $\sim 70 \pm 7 \mathrm{~m}$ y la ZCcC se detectó cercana a la costa a $\sim 300 \mathrm{~m}$. En el otoño, la ZASA $(\sim 125 \mathrm{~m})$ fue más profunda y la ZCcC $(\sim 250 \mathrm{~m})$ ligeramente menor que la temporada anterior.

\section{Estacionalidad de las variables del sistema del $\mathrm{CO}_{2}$}

La variación estacional de las variables del sistema del $\mathrm{CO}_{2}$ mostró buena concordancia con la distribución de las masas de agua. Por ejemplo, se detectó agua con un alto contenido de DIC $\left(\sim 2,180 \mu \mathrm{mol} \cdot \mathrm{kg}^{-1}\right)$ y bajos valores de $\Omega$ a en invierno, cuando las isopicnas subieron a $\sim 80 \mathrm{~m}$ de profundidad en dirección a la costa (Fig. 5). El Z $\Omega$ a más somero cerca de la costa no se encontró durante la temporada de surgencias costeras más intensas (primavera-verano), sino en invierno. Adicionalmente, el mayor levantamiento de las isopicnas hacia la costa coincidió con la época en la que La Niña fue más intensa.

\section{Influencia de condiciones interanuales}

La relación entre la ZASA y el ONI mostró que cuando los valores del ONI fueron negativos, la ZASA se localizó a menor profundidad (Fig. 6). Por ejemplo, en el invierno de 2010-2011 y bajo condiciones de La Niña, la ZASA se detectó a $102 \mathrm{~m}$ y los valores de ONI fueron de $-1.3{ }^{\circ} \mathrm{C}$. En contraste, en el invierno de 1998, pero bajo condiciones de El Niño, la ZASA se detectó a $162 \mathrm{~m}$ y el ONI fue de $+2.1{ }^{\circ} \mathrm{C}$. Según el análisis de regresión lineal, el ONI explicó el $60 \%$ $\left(r^{2}=0.6, P<0.01, n=12\right)$ de la variabilidad temporal que presentó la posición de la ZASA.

Las estaciones de muestreo internas y aledañas a la BTS presentaron aguas salinas $(>33.4)$ y valores de $\Omega \mathrm{a}<1$.6. Sin embargo, fuera de la BTS el escenario fue lo contrario debido al dominio del ASA (principalmente en invierno) (Fig. 7). Durante el invierno, un frente norte-sur paralelo a la costa 

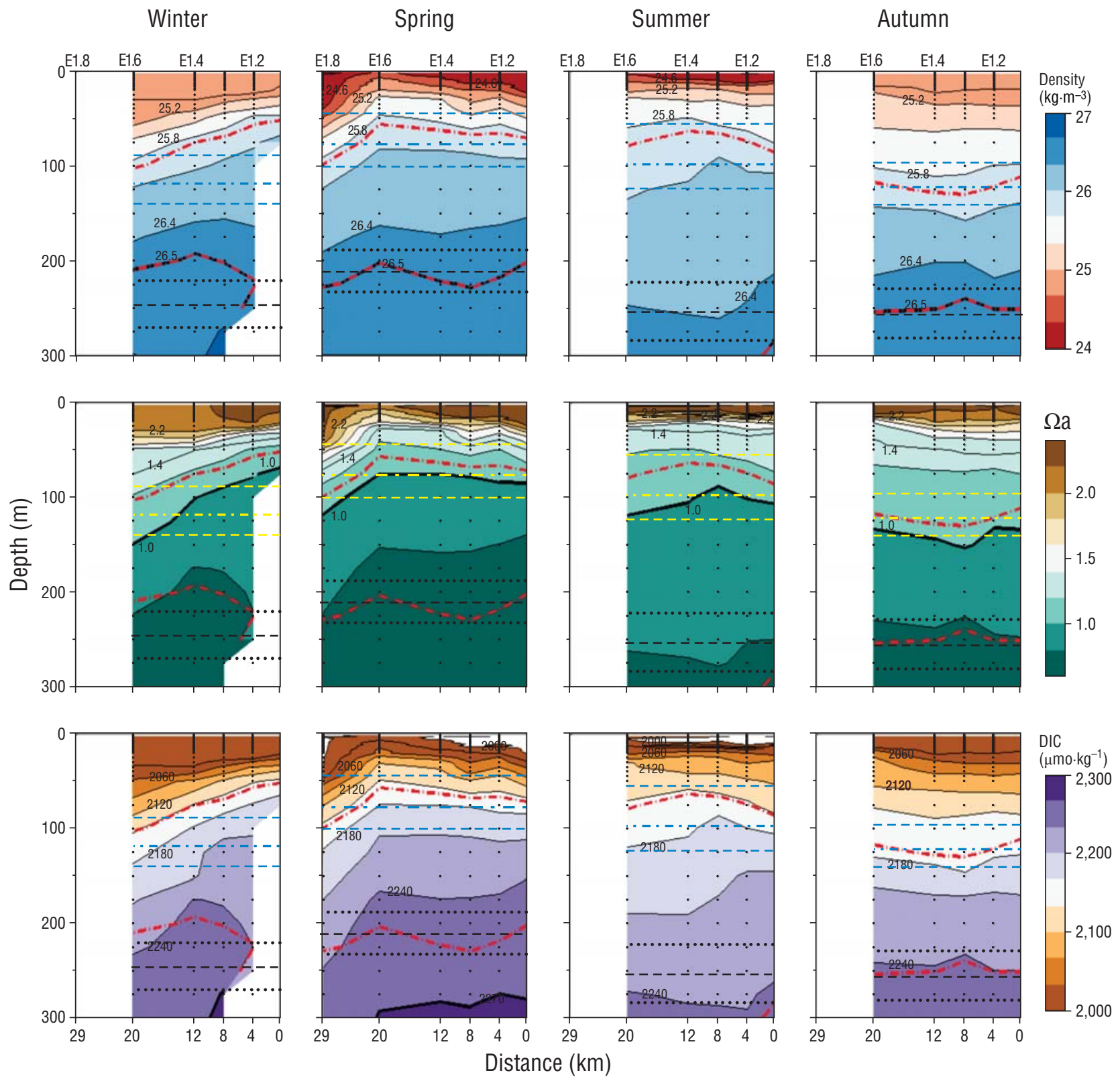

Figure 5. Seasonal variations of density, aragonite saturation state $(\Omega \mathrm{a})$, and dissolved inorganic carbon (DIC) by depth along transect E1 (southern portion of our study area) in Todos Santos Bay. The red dash-dot lines indicate the $25.9 \mathrm{~kg} \cdot \mathrm{m}^{-3} \mathrm{and} 26.5 \mathrm{~kg} \cdot \mathrm{m}^{-3}$ isopycnals, which correspond to the lower limit of the Subarctic Water and to the locations of core of the California Countercurrent, respectively. The horizontal dashed lines represent the average depth of these isopycnals during the 1997-2011 period at stations 100.30-100.35 of the IMECOCAL program.

Figura 5. Variación estacional de la densidad, del estado de saturación del aragonita, y del carbono inorgánico disuelto (DIC) con la profundidad a lo largo del transecto E1 (parte sur de nuestra área de estudio) en la bahía de Todos Santos. Las líneas rojas discontinuas con puntos indican las isopicnas de $25.9 \mathrm{~kg} \cdot \mathrm{m}^{-3}$ y $26.5 \mathrm{~kg} \cdot \mathrm{m}^{-3}$, las cuales corresponden al límite inferior del Agua del Subártico y las ubicaciones del núcleo de la contracorriente de California, respectivamente. Las líneas discontinuas horizontales representan la profundidad promedio de estas isopicnas durante el periodo entre 1997-2011 en las estaciones 100.30-100.35 del programa IMECOCAL 


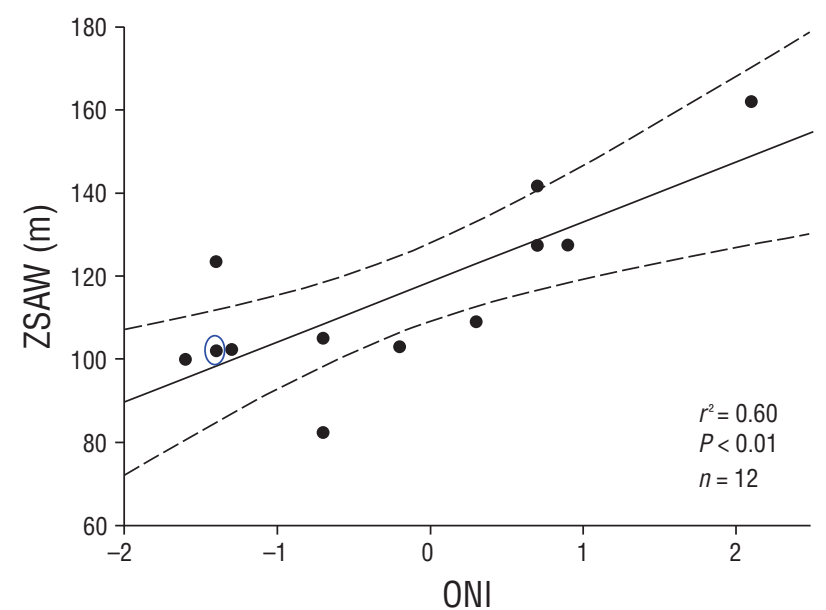

Figure 6. Average depth of the Subarctic Water boundary corresponding to the $25.9 \mathrm{~kg} \cdot \mathrm{m}^{-3}$ isopycnal (ZSAW) plotted against the Oceanic Niño Index (ONI). Data are for the cruises carried out by the IMECOCAL program along line 100 from December to February 1998-2012. The blue circle denotes the values for 2011.

Figura 6. Profundidad promedio del límite del Agua del Subártico que corresponde a la isopicna de $25.9 \mathrm{~kg} \cdot \mathrm{m}^{-3}$ (ZSAW) graficada contra el Índice Oceánico de El Niño (ONI). Los datos son de los cruceros realizados por el programa IMECOCAL a lo largo de la línea 100 de diciembre a febrero de 1998-2012. El círculo azul indica los valores para 2011 .

\section{Vertical variation of $\mathrm{Z} \Omega \mathrm{a}$}

ZRa fluctuated spatially and seasonally (Fig. 8). In winter it was less than $60 \mathrm{~m}$ close to shore and it gradually increased offshore until reaching values $>140 \mathrm{~m}$. This scenario changed in spring, with a shallower horizon throughout most of the study area. In TSB Z 2 a was shallower $(30 \mathrm{~m})$ but in the more oceanic region it was $\sim 80 \mathrm{~m}$. In summer, $\mathrm{Z} \Omega \mathrm{a}$ was generally deeper in the northwestern area $(>140 \mathrm{~m})$, and it showed a positive gradient toward the south $(120-100 \mathrm{~m})$. However, the gradient was less pronounced toward the Todos Santos Islands, where it was located at shallower depths, between 60 and $80 \mathrm{~m}$. In autumn, $\mathrm{Z} \Omega$ a was located at $>140 \mathrm{~m}$ in the northeastern and central portions of the sampling area where the outer stations were located. $\mathrm{Z} \Omega \mathrm{a}$ was shallower toward TSB.

\section{Contrast between the oceanography in and out of Todos Santos Bay}

The inner and outer TSB stations showed differences in physical and chemical variables only during winter and spring (Fig. 8). The most relevant observation was that, in winter and spring, temperature and $\Omega \mathrm{a}$ were lower and salinity was higher in TSB than in the oceanic waters outside the bay (Fig. 8). Salinity helped understand the differences we found. For example, the highest salinity variability (33.0-34.5) was found at stations outside TSB; however, toward the bay most salinity values were higher than the average, and $\Omega \mathrm{a}(0.5-3.0)$ separó a las aguas de la BTS de las aguas aledañas a la bahía, las cuales presentaron baja salinidad $(<33.3)$ y valores altos de $\Omega$ a (>2.2). Por otra parte, en la primavera se encontraron características similares a las condiciones de invierno. En el verano, agua menos salina $(\sim 33.3)$ se distribuyó principalmente al noroeste de la zona de muestreo y presentó valores de $\Omega$ a de $\sim 2.2$. Durante el otoño ocurrió lo contrario a lo observado en el verano, ya que agua menos salina se observó en el área de estudio de norte a sur a manera de intrusión (Fig. 7d).

\section{Variación vertical del Z $\Omega \mathrm{a}$}

El Z aa fluctuó de forma espacial y estacional (Fig. 8). En el invierno se encontró a menos de $60 \mathrm{~m}$ hacia la costa $\mathrm{y}$, gradualmente, aumentó hacia mar adentro hasta alcanzar valores $>140 \mathrm{~m}$. Este escenario cambió en primavera, con un horizonte con menor profundidad en casi toda el área de estudio. Dentro de la BTS el Z $\Omega$ a fue más somero $(30 \mathrm{~m})$, y hacia la porción más oceánica, se encontró a alrededor de $80 \mathrm{~m}$. En el verano, el Z $\mathrm{Za}$ se encontró, generalmente, a mayor profundidad en la zona noroeste $(>140 \mathrm{~m})$, presentando un gradiente positivo hacia el sur (120-100 m). Sin embargo, el gradiente fue menos marcado hacia las islas Todos Santos, localizándose a profundidades más someras de entre 60 y $80 \mathrm{~m}$. Para el otoño, el Z $\Omega$ a se ubicó a $>140 \mathrm{~m}$ en el noreste $\mathrm{y}$ en el centro de la zona de muestreo donde se localizaron las estaciones externas a la BTS. Hacia el interior de la BTS, el $\mathrm{Z} \Omega$ a fue más someró.

\section{Contraste de la oceanografía del interior y el exterior de la bahía de Todos Santos}

Las estaciones internas y externas de BTS presentaron diferencias en las variables físicas y químicas solo durante invierno y primavera (Fig. 8). Lo relevante fue que en la BTS, durante invierno y primavera, se observaron valores de temperatura y $\Omega$ a más bajos y salinidad más alta que en las aguas oceánicas del exterior de la bahía (Fig. 8). La salinidad contribuyó a entender las diferencias encontradas. Por ejemplo, la mayor variabilidad de salinidad (33.0-34.5) se encontró en las estaciones externas a la BTS; sin embargo, hacia el interior de la BTS la salinidad en la mayoría de los casos presentó valores por arriba del promedio, mientras que los valores de $\Omega \mathrm{a}(0.5-3)$ y la temperatura $\left(3-19^{\circ} \mathrm{C}\right)$ fueron mayores con respecto a los valores climatológicos en 0.5 unidades y $4{ }^{\circ} \mathrm{C}$, respectivamente.

\section{Relación entre la ZASA y el Z $\Omega a$}

Las condiciones de La Niña de 2011 fueron más intensas en invierno, lo cual se reflejó en la posición más somera de la ZASA en comparación con la climatología para esa estación del año (Fig. 9). Esta diferencia se detectó al comparar

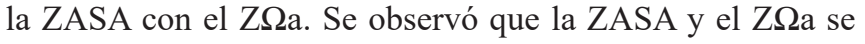




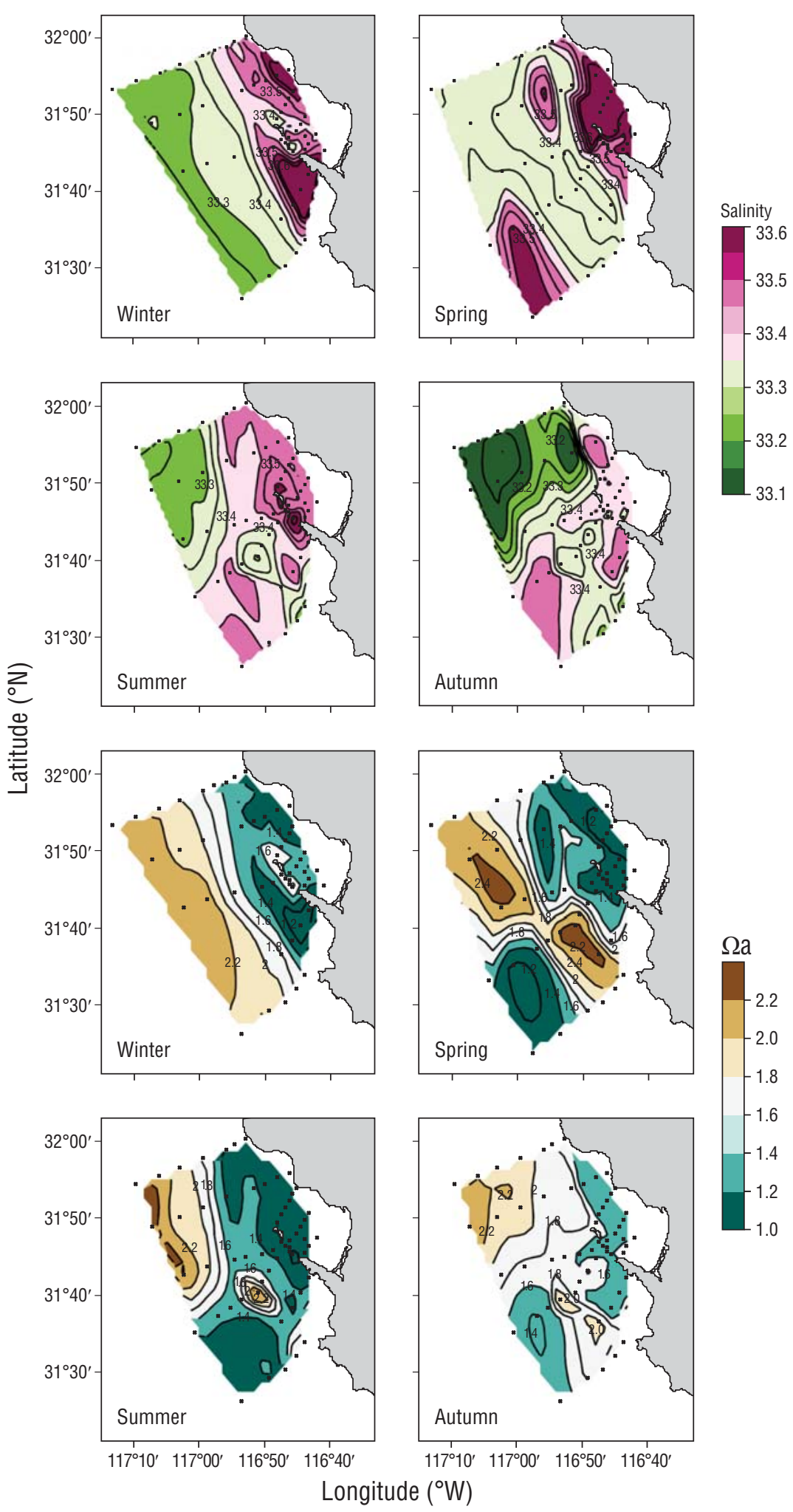

Figure 7. Spatial distribution of salinity and the aragonite saturation state $(\Omega \mathrm{a})$ at $30 \mathrm{~m}$ depth during the 2011 winter, spring, summer, and autumn cruises in the Todos Santos Bay region and surrounding waters.

Figura 7. Distribución espacial de la salinidad y del estado de saturación del aragonita $(\Omega \mathrm{a})$ a $30 \mathrm{~m}$ de profundidad durante los cruceros de invierno, primavera, verano y otoño en la región de la bahía de Todos Santos y aguas adyacentes. 


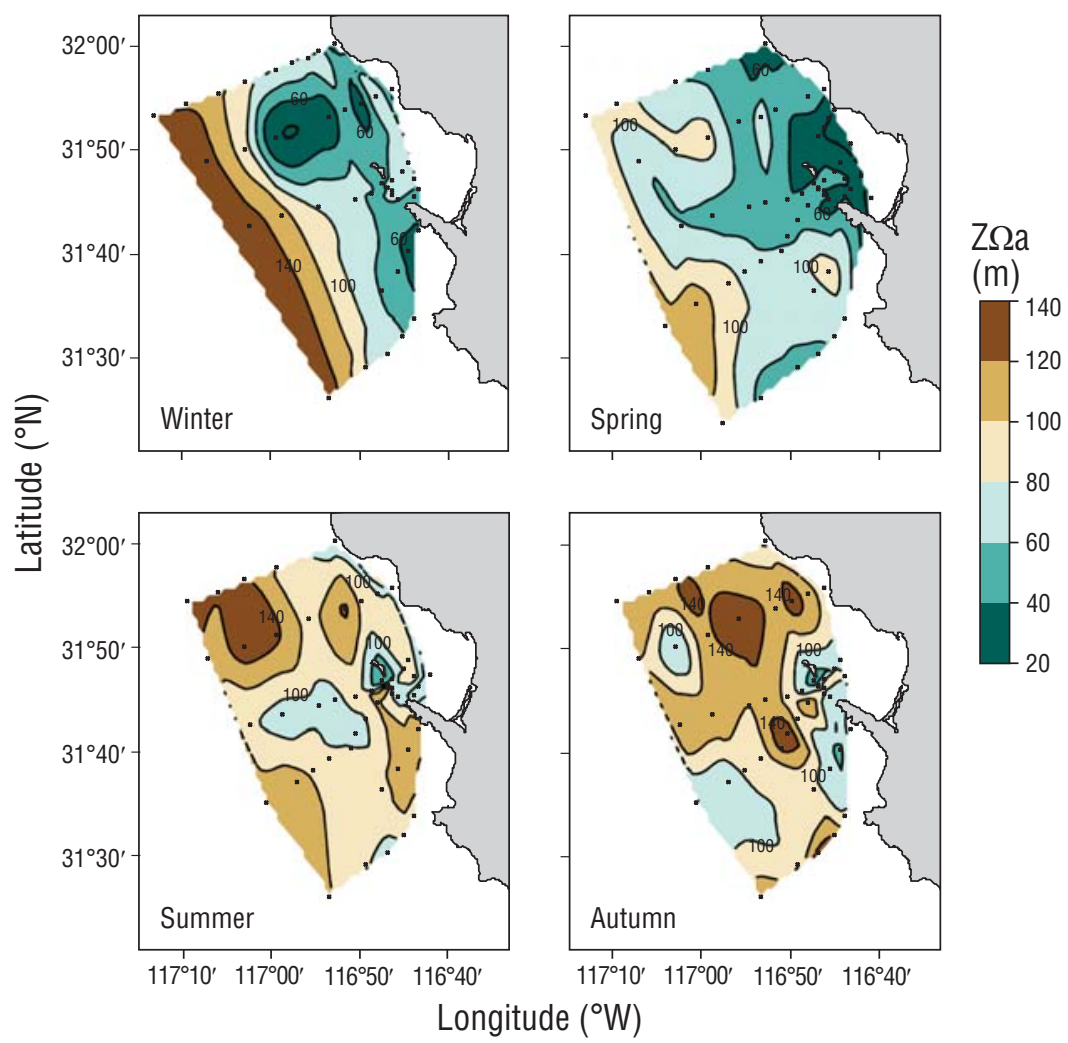

Figure 8. Spatial distribution of the aragonite saturation horizon (Z $\Omega$ a) at $30 \mathrm{~m}$ depth during the 2011 winter, spring, summer, and autumn cruises in the Todos Santos Bay region and surrounding waters.

Figura 8. Distribución espacial del horizonte de saturación del aragonita a $30 \mathrm{~m}$ de profundidad durante los cruceros de invierno, primavera, verano y otoño en la región de la bahía de Todos Santos y aguas adyacentes.

and temperature $\left(3-19^{\circ} \mathrm{C}\right)$ values were higher with respect to the climatological values by 0.5 units and $4{ }^{\circ} \mathrm{C}$, respectively.

\section{Relationship between ZSAW and Z $\Omega \mathbf{a}$}

The 2011 La Niña conditions were more intense in winter; this was reflected in the position of ZSAW, which was shallower compared to the climatology for that season (Fig. 9). This difference was detected by comparing ZSAW with Z $\Omega$ a. ZSAW and Z $\Omega$ a were located at approximately the same position during the winter $\left(r_{\text {pearson }}=0.78, n=42, P<0.05\right)$, spring $\left(r_{\text {pearson }}=0.70, n=52, P<0.05\right)$, and summer $\left(r_{\text {pearson }}=0.78\right.$, $n=49, P<0.05)$ cruises; this was not the case for autumn ( $\left.r_{\text {pearson }}=0.54 n=46, P<0.05\right)$ (Fig. 9).

\section{Discussion}

\section{Influence of Subarctic Water on the position of $\mathrm{Z} \Omega \mathrm{a}$}

In this study we found that the distribution of $\mathrm{Z} \Omega \mathrm{a}$ corresponded with the distribution of the characteristics of the water masses in the region. Therefore, higher proportions of $\mathrm{SAW}$ in the water column result in deeper positions of $\mathrm{Z} \Omega \mathrm{a}$. This behavior was observed mainly in winter and spring localizaron aproximadamente en la misma posición durante los cruceros de invierno $\left(r_{\text {pearson }}=0.78, n=42, P<0.05\right)$, primavera $\left(r_{\text {pearson }}=0.70, n=52, P<0.05\right)$ y verano $\left(r_{\text {pearson }}=\right.$ $0.78, n=49, P<0.05)$, a diferencia del otoño $\left(r_{\text {pearson }}=0.54\right.$, $n=46, P<0.05$ ) (Fig. 9).

\section{Discusión}

\section{Influencia del Agua del Subártico sobre la posición del Z $\Omega a$}

En este estudio se encontró que la distribución del $\mathrm{Z} \Omega \mathrm{a}$ corresponde a la distribución de las características de las masas de agua en la región, de tal manera que a mayor proporción de ASA en la columna de agua, mayor $\mathrm{Z} \Omega \mathrm{a}$. Esta característica se observó principalmente en el invierno y la primavera de 2011, cuando la corriente de California fue anómalamente más intensa durante La Niña, como se reportó en otros trabajos para la parte sur de la corriente de California (Bjorkstedt et al. 2012, Jacox et al. 2016, Rudnick et al. 2017). Durante las condiciones de La Niña un predominio de ASA fue detectado en la parte más oceánica, pero el agua fue más salina dentro de la BTS. Estas condiciones, por consiguiente, cambiaron la química de los carbonatos. 
2011, when the California Current was anomalously more intense during La Niña, as was reported in other studies for the southern part of the California Current (Bjorkstedt et al. 2012, Jacox et al. 2016, Rudnick et al. 2017). During La Niña conditions, SAW predominated in the more oceanic section, but water in TSB was saltier. These conditions consequently changed the chemistry of carbonates.

\section{Oceanographic conditions in 2011}

In winter and spring, SAW predominates off the northern coasts of Baja California, while in autumn and winter the California Countercurrent is more intense and transports Equatorial Subsurface Water (ESsW) in a northward direction (Linacre et al. 2010a, Durazo 2015). However, under the 2011 La Niña conditions, the oceanographic scenario was different. Strong anticyclonic wind anomalies were present in the North Pacific, prompting cooling conditions, as reflected by the negative sea surface temperature anomalies in the CCS that lasted until September-October 2011 (Bjorkstedt et al. 2012).

The negative ONI anomalies $\left(-1.5^{\circ} \mathrm{C}\right)$ recorded during 2011 were slightly weaker than those detected during the 2008 La Niña event (ONI values of approximately $-2{ }^{\circ} \mathrm{C}$ ). During this 2008 event, there were pulses of DIC-rich water, with high nutrient concentrations and noticeable effects on the diversity of the phytoplankton community (Linacre et al. 2010a, b; 2012). The results of this study suggest that the most evident effect of the 2011 La Niña event was the presence of

\section{Condiciones oceanográficas en 2011}

Durante el invierno y la primavera, el ASA domina la porción norte de las costas de Baja California, mientras que en el otoño y el invierno la contracorriente de California es más intensa y transporta Agua Ecuatorial Subsuperficial (AESs) con dirección hacia el norte (Linacre et al. 2010a, Durazo 2015). Sin embargo, ante las condiciones de La Niña de 2011, el escenario oceanográfico fue distinto. En el Pacífico Norte se presentaron fuertes anomalías de viento anticiclónicas, lo cual propició un enfriamiento, reflejado en las anomalías negativas de la temperatura superficial del mar que se mantuvieron en el SCC hasta septiembre-octubre de 2011 (Bjorkstedt et al. 2012).

Durante 2011 se registraron anomalías negativas del ONI $\left(-1.5^{\circ} \mathrm{C}\right)$ que fueron ligeramente más débiles que las detectadas durante La Niña de 2008 (ONI de aproximadamente $-2{ }^{\circ} \mathrm{C}$ ). Durante ese evento de 2008 se identificaron pulsos de agua rica en DIC, con altas concentraciones de nutrientes y efectos observables en la diversidad de la comunidad fitoplanctónica (Linacre et al. 2010a, b; 2012). Los resultados de este estudio sugieren que el efecto más evidente de La Niña de 2011 fue la presencia de aguas más frías y menos salinas de lo normal, particularmente en invierno. Estos resultados son consistentes con el hecho de que La Niña de 2011 fue más intensa en invierno y gradualmente perdió intensidad hacia finales de ese año.

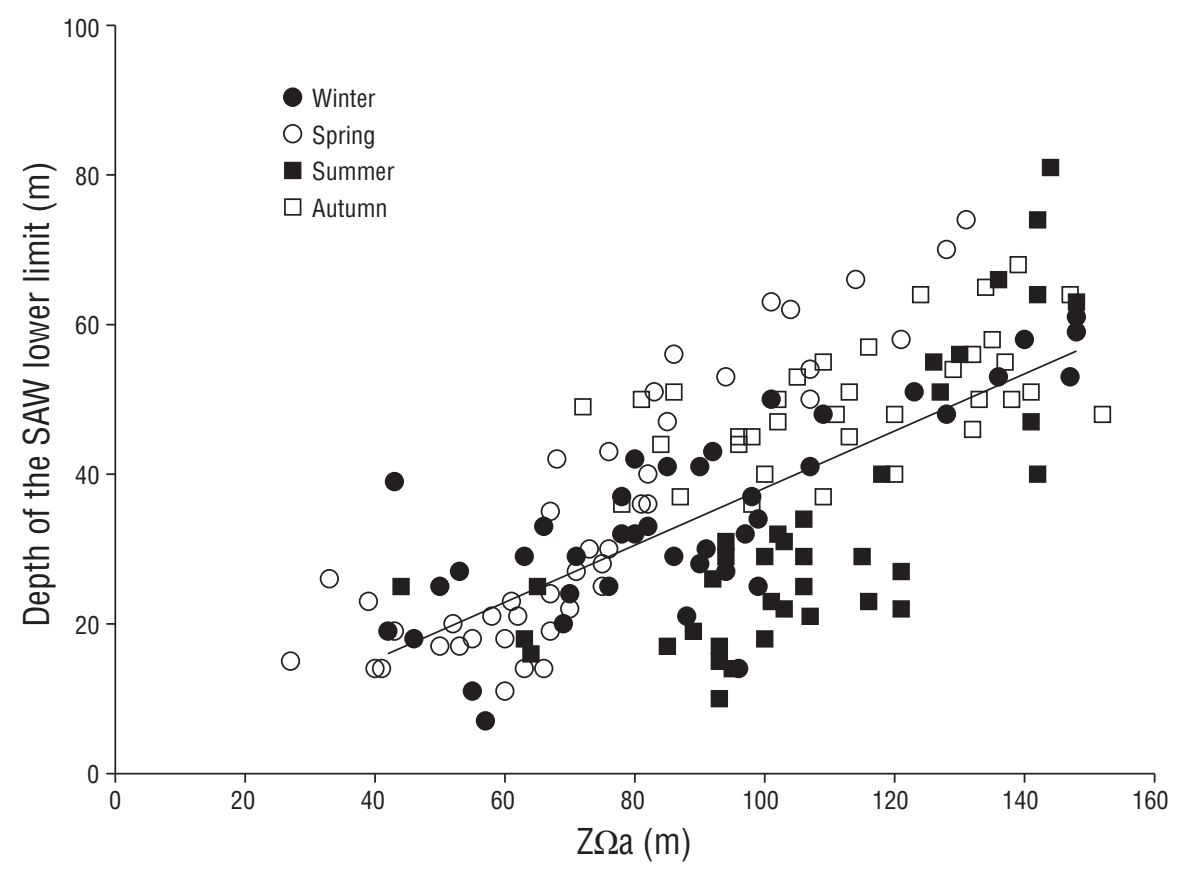

Figure 9. Aragonite saturation horizon ( $\mathrm{Z} \Omega \mathrm{a}$ ) against depth of the $25.9 \mathrm{~kg} \cdot \mathrm{m}^{-3}$ isopycnal, which corresponds to the lower limit of the Subarctic Water (SAW).

Figura 9. Horizonte de saturación del aragonita (Z $\Omega$ a) contra la profundidad de la isopicna de $25.9 \mathrm{~kg} \cdot \mathrm{m}^{-3}$, la cual corresponde al límite inferior del Agua del Subártico (SAW). 
water that was colder and less saline than normal, particularly in winter. These results are consistent with the fact that the 2011 La Niña event was more intense in winter and gradually lost intensity toward the end of that year.

In the present study the thermohaline structure above $300 \mathrm{~m}$ depth was formed by 2 water masses, SAW, which is less saline ( $\sim 33.3)$, and ESsW, which shows higher salinity values ( 34.4), in agreement with what other authors have reported (Durazo and Baumgartner 2002, Durazo 2015). Both of these water masses are transported by the California Current and the California Countercurrent, respectively, along the coasts of Baja California (Durazo and Baumgartner 2002, Pérez-Brunius et al. 2006, Durazo 2015). Several studies have indicated that, over the continental shelf of Baja California, from spring to autumn, the poleward subsurface countercurrent is more intense and advects ESsW (Lynn and Simpson 1987, Linacre et al. 2010a, Durazo 2015). At depths of $\sim 150 \mathrm{~m}$, ESsW mixes with SAW and forms transitional water, which we consider is responsible for values of $\Omega \mathrm{a}=1$. The proportion of this water masses will determine if $\mathrm{Z} \Omega \mathrm{a}$ deepens when SAW predominates or if it shoals when the ESsW signal intensifies. However, the proportion and distribution of water masses on the coasts of Baja California change during events like El Niño and La Niña (Durazo and Baumgartner 2002). Therefore, a combination of interannual conditions promotes changes in the magnitude of the carbonate system variables in the water column of the southern portion of the CCS.

An example of the influence of interannual conditions in the southern portion of the CCS in relation to the signal of the $\mathrm{CO}_{2}$ system was reported by Friederich et al. (2002) for the coasts of Monterey Bay (California, USA). These authors carried out $\mathrm{CO}_{2}$ partial pressure $\left(\mathrm{pCO}_{2}\right)$ surface measurements during the 1997-1998 El Niño and La Niña events and reported high surface $\mathrm{pCO}_{2}$ concentrations during La Niña conditions and values near equilibrium with respect to the atmosphere during El Niño conditions because there were no upwelling events during that period. Another example is shown in a study carried out on the coasts of San Diego (California, USA) during the 2010 La Niña conditions, in which Nam et al. (2011) detected low $\mathrm{pH}$ values and the upward movement of isopycnals toward the coast. Similarly, another study carried out during the 2011 La Niña event on the coasts of San Diego detected temperature and salinity anomalies of -1.5 and -0.1 , respectively (Rudnick et al. 2017), and the upward movement of the $26.0 \mathrm{~kg} \cdot \mathrm{m}^{-3}$ isopycnal by about $20 \mathrm{~m}$ from an average depth of $150 \mathrm{~m}$ (Jacox et al. 2016).

Interannual events undoubtedly affect the regional oceanography and, in turn, thermohaline variables and water chemistry. A recently published study on $\mathrm{pCO}_{2}$ measurements obtained during 2011 at the Ensenada station (Coronado-Álvarez et al. 2017) reported the presence of upwelling episodes with high $\mathrm{CO}_{2}$ fluxes (up to $3.8 \mathrm{mmol}$ $\left.\mathrm{C} \cdot \mathrm{m}^{-2} \cdot \mathrm{h}^{-1}\right)$ and low temperatures $\left(\sim 10^{\circ} \mathrm{C}\right)$. High $\mathrm{pCO}_{2}$ values indicate that $\mathrm{pH}$ was lower during that year, as were $\Omega$ a values.
En coincidencia con lo reportado por otros autores (Durazo y Baumgartner 2002, Durazo 2015), en el presente trabajo se encontró que la estructura termohalina por arriba de los $300 \mathrm{~m}$ de profundidad estuvo conformada por 2 masas de agua, el ASA, que se caracteriza por ser menos salina ( 33.3), y el AESs, que presenta salinidades más elevadas $(\sim 34.4)$. Ambas masas de agua son transportadas por la corriente de California y la contracorriente de California, respectivamente, a lo largo de las costas de Baja California (Durazo y Baumgartner 2002, Pérez-Brunius et al. 2006, Durazo 2015). Diversos trabajos han señalado que desde la primavera hasta el otoño, sobre la plataforma continental de la península de Baja California, se presenta con mayor intensidad la contracorriente subsuperficial con dirección hacia el polo, la cual advecta AESs (Lynn y Simpson 1987, Linacre et al. 2010a, Durazo 2015). A profundidades de $\sim 150 \mathrm{~m}$, la AESs se mezcla con ASA y genera agua transicional, de la cual consideramos resultan los valores de $\Omega \mathrm{a}=1$. La proporción con que se presenten estas masas de agua determinará que el $Z \Omega$ a sea mayor cuando predomine el ASA o que sea más somero si se intensifica la señal del AESs. Sin embargo, la proporción y la distribución con que se presentan las masas de agua en las costas de Baja California cambian durante eventos como El Niño o La Niña (Durazo y Baumgartner 2002). Por tanto, la combinación de condiciones interanuales promueve cambios en la magnitud de las variables del sistema de los carbonatos en la columna de agua de la región sur del SCC.

Un ejemplo de la influencia de las condiciones interanuales en el sur del SCC con relación a la señal del sistema del $\mathrm{CO}_{2}$ es el reportado por Friederich et al. (2002) para las costas de la bahía de Monterrey (California, EUA). Estos autores realizaron mediciones superficiales de la presión parcial del $\mathrm{CO}_{2}\left(\mathrm{pCO}_{2}\right)$ durante los eventos de El Niño y La Niña de 1997-1998 y reportaron altas concentraciones superficiales de $\mathrm{pCO}_{2}$ durante condiciones de La Niña y valores cercanos al equilibrio con la atmósfera durante condiciones de El Niño debido a que durante ese periodo no se presentaron eventos de surgencia. Otro ejemplo es mostrado en un estudio realizado en las costas de San Diego (California, EUA) durante condiciones de La Niña de 2010, en el cual Nam et al. (2011) detectaron valores del $\mathrm{pH}$ bajos y un ascenso de las isopicnas en dirección a la costa. De igual forma, en otro estudio realizado durante La Niña de 2011 en las costas de San Diego se detectaron anomalías negativas de temperatura y salinidad con valores de -1.5 y -0.1 , respectivamente (Rudnick et al. 2017), y un ascenso de la isopicna de $26.0 \mathrm{~kg} \cdot \mathrm{m}^{-3} \mathrm{de} \sim 20 \mathrm{~m}$ a partir de una profundidad promedio de $150 \mathrm{~m}$ (Jacox et al. 2016).

Los eventos interanuales tienen, sin duda, efectos en la oceanografía regional y, por ende, en las variables termohalinas y la química del agua. En un estudio publicado recientemente sobre mediciones de $\mathrm{pCO}_{2}$ durante 2011 en la estación Ensenada (Coronado-Álvarez et al. 2017) se reportó la presencia de episodios de surgencias con altos flujos de $\mathrm{CO}_{2}$ (hasta $\left.3.8 \mathrm{mmol} \mathrm{C} \cdot \mathrm{m}^{-2} \cdot \mathrm{h}^{-1}\right)$ y bajas temperaturas $\left(\sim 10{ }^{\circ} \mathrm{C}\right)$. 
Our study on TSB during the 2011 La Niña event suggests the presence of anomalously cold, less-saline SAW in the most oceanic region and saltier water in TSB. Also in TSB, $\mathrm{pH}(<7.7)$ values were the lowest and high DIC concentrations $\left(2,200 \mu \mathrm{mol} \cdot \mathrm{kg}^{-1}\right)$ were detected at shallower depths near the coast $(\leq 100 \mathrm{~m})$ in winter and spring.

\section{Comparison of physical and chemical conditions in and out of Todos Santos Bay}

La Niña effects were reflected on the hydrographic conditions at both the IMECOCAL stations (coast and ocean) and the stations adjacent to TSB. Using the T-S diagrams, we detected that the characteristics of water masses at the IMECOCAL stations were similar to those detected at stations outside TSB. However, in winter and spring, water was more saline in TSB and near the coast (Fig. 8). As mentioned above, this could be attributed to the entrance of subsurface water to TSB during upwelling events, which contributed to the perpetuity of this water in TSB due to water recirculation in the bay (Delgadillo-Hinojosa et al. 2015).

The results of this study suggest that $\mathrm{Z} \Omega \mathrm{a}$ was located at $30 \mathrm{~m}$, that is, $10 \mathrm{~m}$ shallower than what Feely et al. (2008) reported for waters off TSB and adjacent areas. There were no previous records of $\mathrm{Z} \Omega \mathrm{a}$ for $\mathrm{TSB}$, nor that it could be so shallow $(30 \mathrm{~m})$, as reported in this study. This could pose a threat to organisms in the area that use carbonate to calcify their structures in their first life stages. For example, larval development for the oyster Crassostrea gigas requires optimum values of $\Omega \mathrm{a}>1.6$ (Barton et al. 2012). Therefore, if values of $\Omega \mathrm{a}=1$ at $\sim 20 \mathrm{~m}$ depth during intense upwelling events in TSB, conditions may be unfavorable for some calcifying species that inhabit this area.

This study contributes to the advancement of knowledge on the carbonate system in TSB. Though the results of this study are based on punctual observations and model reconstructions, information here shows that characteristics during events such as La Niña can produce different oceanographic scenarios that affect the carbonate system in TSB coastal waters. In addition, the results suggest that $\mathrm{Z} \Omega \mathrm{a}$ was particularly shallow during the 2011 La Niña event, mainly at the beginning of the year (winter), and this could potentially influence the proper development of the larval stages of calcifying organisms in the area.

\section{ACKNOWLEDGMENTS}

This study was supported by The National Council for Science and Technology (Mexico, projects CB 2008-01-098471 and CB-2008-01/106153) and by the Autonomous University of Baja California (project 403/1/C/99/12). We also thank the NOAA Global Carbon Cycle and Ocean Acidification programs for allowing us to use the oceanographic data.

English translation by Claudia Michel-Villalobos.
Los valores de $\mathrm{pCO}_{2}$ altos reflejan que el $\mathrm{pH}$ fue más bajo, al igual que los valores de $\Omega$ a, durante ese año.

Los resultados de este estudio en la BTS durante La Niña de 2011 sugieren la presencia de ASA anómalamente fría y menos salina en la parte más oceánica y agua más salina dentro de la BTS. Además, en el interior de la BTS se encontraron los valores más bajos del $\mathrm{pH}(<7.7)$ y se detectaron altas concentraciones de DIC $\left(2,200 \mu \mathrm{mol} \cdot \mathrm{kg}^{-1}\right)$ a menor profundidad cerca de la costa $(\leq 100 \mathrm{~m})$ en el invierno y la primavera.

\section{Comparación de condiciones físicas y químicas dentro y fuera de la bahía de Todos Santos}

Los efectos de La Niña se reflejaron en las condiciones hidrográficas, tanto en las estaciones del programa IMECOCAL (costa y océano) como en las estaciones aledañas a la BTS. Con base en los diagramas T-S, se detectó que las características de las masas de agua que se observaron en las estaciones IMECOCAL fueron similares a las que se detectaron en las estaciones fuera de la BTS. Sin embargo, durante el invierno y la primavera, se encontró agua más salina dentro de la BTS y en zonas aledañas a la costa (Fig. 8). Como se mencionó anteriormente, esto podría atribuirse a la entrada de agua subsuperficial a la BTS durante eventos de surgencia, los cuales contribuyeron a que esta agua permaneciera dentro de la BTS debido a la recirculación del agua en el interior de la bahía (Delgadillo-Hinojosa et al. 2015).

Los resultados de este trabajo sugieren que el $Z \Omega a$ se encontró a $30 \mathrm{~m}$, es decir, $10 \mathrm{~m}$ más somero que lo que reportaron Feely et al. (2008) para las aguas frente a la BTS y zonas aledañas. No se tenían registros del $Z \Omega$ a para la zona dentro de la BTS, tampoco de que pudiera ser tan somero $(30 \mathrm{~m})$, como se encontró en este trabajo. Esto podría representar una alerta para organismos de la zona que utilizan carbonato para calcificar sus estructuras en sus primeros estadios de vida. Por ejemplo, el desarrollo de las larvas del ostión Crassostrea gigas requiere de valores óptimos de $\Omega \mathrm{a}>1.6$ (Barton et al. 2012). Por lo tanto, si los valores de $\Omega \mathrm{a}=1$ se presentan a $\sim 20 \mathrm{~m}$ de profundidad en la BTS durante eventos intensos de surgencia, podrían existir condiciones que pudieran ser no apropiadas para algunas especies calcificadoras que habitan en esta región.

Este trabajo contribuye a aumentar el conocimiento del sistema de los carbonatos en la BTS. Si bien los resultados de este estudio están basados en observaciones puntuales y reconstruidas con modelos, esta información muestra que las características que se presenten durante eventos como el de La Niña pueden generar diferentes escenarios oceanográficos con efecto en el sistema de los carbonatos de las aguas costeras de la BTS. Además, los resultados sugieren que el Z a durante La Niña de 2011 fue particularmente somero, principalmente al inicio del año (invierno), lo cual potencialmente podría influir en el desarrollo adecuado de los estadios larvales de organismos calcificadores de la zona. 
Oliva-Méndez et al.: The carbonate system during La Niña off northern Baja California

\section{REFERENCES}

Alin SR, Feely RA, Dickson AG, Hernández-Ayón JM, Juranek LW, Ohman MD, Goericke R. 2012. Robust empirical relationships for estimating the carbonate system in the southern California Current System and application to CalCOFI hydrographic cruise data (2005-2011). J. Geophys. Res. Ocean. 117(C5). https://doi.org/10.1029/2011jc007511

Archer D, Kheshgi H, Maier-Reimer E. 1998. Dynamics of fossil fuel $\mathrm{CO}_{2}$ neutralization by marine $\mathrm{CaCO}_{3}$. Global Biogeochem. Cycles 12(2): 259-276. https://doi.org/10.1029/98gb00744

Barton A, Hales B, Waldbusser GG, Langdon C, Feely RA. 2012. The Pacific oyster, Crassostrea gigas, shows negative correlation to naturally elevated carbon dioxide levels: Implications for near-term ocean acidification effects. Limnol. Oceanogr. 57(3): 698-710.

https://doi.org/10.4319/1o.2012.57.3.0698

Bjorkstedt EP, Goericke R, McClatchie S, Weber E, Watson W, Lo N, Peterson WT, Brodeur RD, Auth T, Fisher J, et al. 2012. State of the California Current 2011-2012: Ecosystems respond to local forcing as La Niña wavers and wanes. La Niña. CalCOFI Rep. 53: 41-76.

Bjorkstedt EP, Goericke R, McClatchie S, Weber E, Watson W, Lo N, Peterson B, Emmett B, Brodeur R, Peterson J, et al. 2011. State of the California Current 2010-2011: Regionally variable responses to a strong (but fleeting?) La Niña. CalCOFI Rep. 52: 36-68.

Chhak K, Di Lorenzo E. 2007. Decadal variations in the California Current upwelling cells. Geophys. Res. Lett. 34(14). https://doi.org/10.1029/2007g1030203

Coronado-Álvarez LLA, Álvarez-Borrego S, Lara-Lara JR, SolanaArellano E, Hernández-Ayón JM, Zirino A. 2017. Temporal variations of water $\mathrm{pCO}_{2}$ and the air-water $\mathrm{CO}_{2}$ flux at a coastal location in the southern California Current System: diurnal to interannual scales $=$ Variaciones temporales de $\mathrm{pCO}_{2}$ del agua y flujos aire-agua de $\mathrm{CO}_{2}$ en una localidad costera en el sur del Sistema de la Corriente de California: de la escala diurna a la interanual. Cienc. Mar. 43(3): 137-156. https://doi.org/10.7773/cm.v43i3.2707

Delgadillo-Hinojosa F, Camacho-Ibar V, Huerta-Díaz MA, Torres-Delgado V, Pérez-Brunius P, Lares L, Marinone SG, Segovia JA, Peña-Manjarrez JL, García-Mendoza E, et al. 2015. Seasonal behavior of dissolved cadmium and $\mathrm{Cd} / \mathrm{PO}_{4}$ ratio in Todos Santos Bay: A retention site of upwelled waters in the Baja California peninsula, Mexico. Mari. Chem. 168: 37-48. https://doi.org/10.1016/j.marchem.2014.10.010

Doney SC, Fabry VJ, Feely RA, Kleypas JA. 2009. Ocean Acidification: The Other $\mathrm{CO}_{2}$ Problem. Ann. Rev. Mar. Sci. 1(1): 169-192. https://doi.org/10.1146/annurev.marine.010908.163834

Durazo R. 2015. Seasonality of the transitional region of the California Current System off Baja California. J. Geophys. Res. Ocean. 120(2): 1173-1196.

https://doi.org/10.1002/2014jc010405

Durazo R, Baumgartner TR. 2002. Evolution of oceanographic conditions off Baja California: 1997-1999. Prog. Oceanogr. 54(1-4): 7-31. https://doi.org/10.1016/s0079-6611(02)00041-1

Feely RA, Sabine CL, Hernandez-Ayon JM, Ianson D, Hales B. 2008. Evidence for Upwelling of Corrosive "Acidified" Water onto the Continental Shelf. Science 320(5882): 1490-1492. https://doi.org/10.1126/science.1155676

\section{Agradecimientos}

Este trabajo fue apoyado por el Consejo Nacional de Ciencia y Tecnología (México, proyectos CB 2008-01-098471 y CB-2008-01/106153) y por la Universidad Autónoma de Baja California (proyecto 403/1/C/99/12). Agradecemos a los programas Global Carbon Cycle y Ocean Acidification de la NOAA el haber permitido hacer uso de los datos oceanográficos.

Feely RA, Sabine CL, Lee K, Berelson W, Kleypas J, Fabry VJ, Millero FJ. 2004. Impact of anthropogenic $\mathrm{CO}_{2}$ on the $\mathrm{CaCO}_{3}$ system in the oceans. Science 305(5682): 362-366. https://doi.org/10.1126/science.1097329

Flores-Vidal X, Durazo R, Castro R, Navarro LF, Dominguez F, Gil E. 2015. Fine-scale tidal and subtidal variability of an upwellinginfluenced bay as measured by the Mexican high frequency radar observing system. In: Liu Y, Kerkering H. Weisberg RH (eds.), Coastal Ocean Observing Systems. Elsevier, pp. 209228.

https://doi.org/10.1016/b978-0-12-802022-7.00012-2

Friederich GE, Walz PM, Burczynski MG, Chavez FP. 2002. Inorganic carbon in the central California upwelling system during the 1997-1999 El Nino-La Nina event. Prog. Oceanogr. 54(1-4): 185-203. https://doi.org/10.1016/s0079-6611(02)00049-6

Hernández-Ayón JM, Belli SL, Zirino A. 1999. pH, alkalinity and total $\mathrm{CO}_{2}$ in coastal seawater by potentiometric titration with a difference derivative readout. Anal. Chim. Acta 394(1): 101108.

https://doi.org/10.1016/s0003-2670(99)00207-x

Ilyina T, Zeebe RE. 2012. Detection and projection of carbonate dissolution in the water column and deep-sea sediments due to ocean acidification. Geophys. Res. Lett. 39(6), L06606. https://doi.org/10.1029/2012g1051272

Jacox MG, Hazen EL, Zaba KD, Rudnick DL, Edwards CA, Moore AM, Bograd SJ. 2016. Impacts of the 2015-2016 El Niño on the California Current System: Early assessment and comparison to past events. Geophys. Res. Lett. 43(13): 7072-7080. https://doi.org/10.1002/2016g1069716

Johnson KM, Sieburth JM, Williams PJI, Brändström L. 1987. Coulometric total carbon dioxide analysis for marine studies: automation and calibration. Mar. Chem. 21(2): 117-133. https://doi.org/10.1016/0304-4203(87)90033-8

Juranek LW, Feely RA, Peterson WT, Alin SR, Hales B, Lee K, Sabine CL, Peterson J. 2009. A novel method for determination of aragonite saturation state on the continental shelf of central Oregon using multi-parameter relationships with hydrographic data. Geophys. Res. Lett. 36(24): L24601. https://doi.org/10.1029/2009g1040778

Lewis E, Wallace DWR, Allison LJ. 1998. Program developed for $\mathrm{CO}_{2}$ system calculations. Carbon Dioxide Information Analysis Center, Oak Ridge National Laboratory, Oak Ridge (TN), $21 \mathrm{pp}$. https://doi.org/10.3334/cdiac/otg.co2sys_dos_cdiac105

Linacre L, Durazo R, Hernández-Ayón JM, Delgadillo-Hinojosa F, Cervantes-Díaz G, Lara-Lara JR, Camacho-Ibar V, SiqueirosValencia A, Bazán-Guzmán C. 2010a. Temporal variability of the physical and chemical water characteristics at a coastal monitoring observatory: Station ENSENADA. Cont. Shelf Res. 30(16): 1730-1742. https://doi.org/10.1016/j.csr.2010.07.011 
Linacre L, Landry MR, Cajal-Medrano R, Lara-Lara JR, Hernández-Ayón JM, Mouriño-Pérez RR, García-Mendoza E, Bazán-Guzmán C. 2012. Temporal dynamics of carbon flow through the microbial plankton community in a coastal upwelling system off northern Baja California, Mexico. Mar. Ecol. Prog. Ser. 461: 31-46. https://doi.org/10.3354/meps09782

Linacre LP, Landry MR, Lara-Lara JR, Hernández-Ayón JM, Bazán-Guzmán C. 2010b. Picoplankton dynamics during contrasting seasonal oceanographic conditions at a coastal upwelling station off Northern Baja California, México. J. Plankton Res. 32(4): 539-557. https://doi.org/10.1093/plankt/fbp148

Lynn RJ, Bograd SJ, Chereskin TK, Huyer A. 2003. Seasonal renewal of the California Current: The spring transition off California. J. Geophys. Res. Ocean. 108(C8): 3279. https://doi.org/10.1029/2003jc001787

Lynn RJ, Simpson JJ. 1987. The California Current System: The seasonal variability of its physical characteristics. J. Geophys. Res. Ocean. 92(C12): 12947-12966. https://doi.org/10.1029/jc092ic12p12947

Mehrbach C, Culberson CH, Hawley JE, Pytkowicx RM. 1973. Measurement of the apparent dissociation constants of carbonic acid in seawater at atmospheric pressure. Limnol. Oceanogr. 18(6): 897-907. https://doi.org/10.4319/1o.1973.18.6.0897

Nam S, Kim HJ, Send U. 2011. Amplification of hypoxic and acidic events by La Niña conditions on the continental shelf off California. Geophys. Res. Lett. 38(22): 1-5. https://doi.org/10.1029/2011g1049549

Perez-Brunius, Lopez M, Pares-Sierra A, Pineda JP. 2007. Comparison of upwelling indices off Baja California derived from three different wind data sources. CalCOFI Rep. 48: 204214.

Pérez-Brunius P, López M, Pineda J. 2006. Hydrographic conditions near the coast of northwestern Baja California: 1997-2004. Contin. Shelf Res. 26(8): 885-901. https://doi.org/10.1016/j.csr.2006.01.017

Rudnick DL, Zaba KD, Todd RE, Davis RE. 2017. A climatology of the California Current System from a network of underwater gliders. Prog. Oceanogr. 154: 64-106. https://doi.org/10.1016/j.pocean.2017.03.002

Zaytsev O, Cervantes-Duarte R, Montante O, Gallegos-Garcia A. 2003. Coastal upwelling activity on the Pacific shelf of the Baja California Peninsula. J. Oceanogr. 59(4): 489-502. https://doi.org/10.1023/a:1025544700632

Received October 2017, accepted January 2018. 